\title{
DOCUMENTOS DE TRABAJO Macroprudential Policy and the Inward Transmission of Monetary Policy: the case of Chile, Mexico, and Russia
}

Georgia Bush Tomás Gómez Alejandro Jara David Moreno Konstantin Styrin Yulia Ushakova

N 893 Diciembre 2020 BANCO CENTRAL DE CHILE
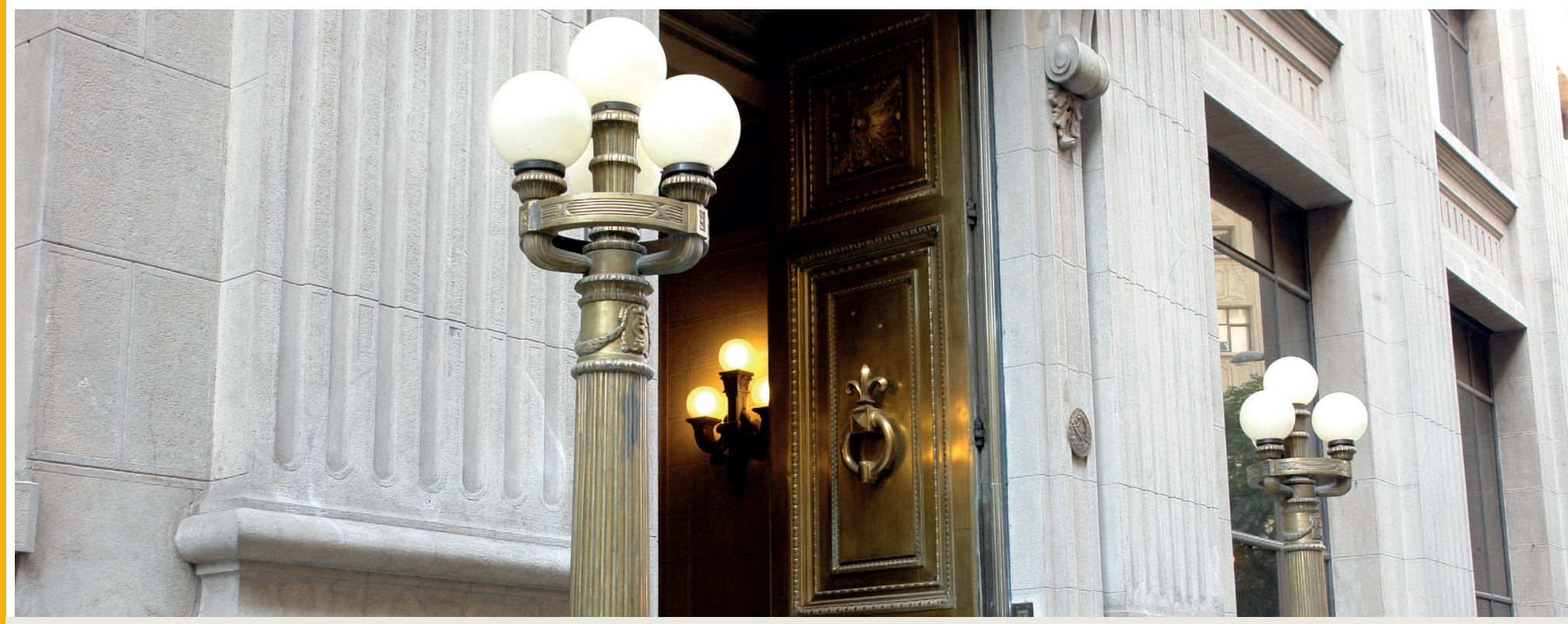


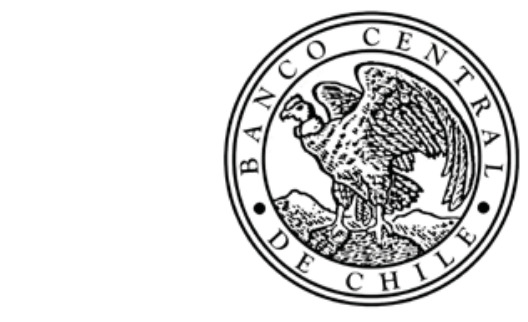

\section{BANCO CENTRAL DE CHILE}

\section{CENTRAL BANK OF CHILE}

La serie Documentos de Trabajo es una publicación del Banco Central de Chile que divulga los trabajos de investigación económica realizados por profesionales de esta institución o encargados por ella a terceros. El objetivo de la serie es aportar al debate temas relevantes y presentar nuevos enfoques en el análisis de los mismos. La difusión de los Documentos de Trabajo sólo intenta facilitar el intercambio de ideas y dar a conocer investigaciones, con carácter preliminar, para su discusión y comentarios.

La publicación de los Documentos de Trabajo no está sujeta a la aprobación previa de los miembros del Consejo del Banco Central de Chile. Tanto el contenido de los Documentos de Trabajo como también los análisis y conclusiones que de ellos se deriven, son de exclusiva responsabilidad de su o sus autores y no reflejan necesariamente la opinión del Banco Central de Chile o de sus Consejeros.

The Working Papers series of the Central Bank of Chile disseminates economic research conducted by Central Bank staff or third parties under the sponsorship of the Bank. The purpose of the series is to contribute to the discussion of relevant issues and develop new analytical or empirical approaches in their analyses. The only aim of the Working Papers is to disseminate preliminary research for its discussion and comments.

Publication of Working Papers is not subject to previous approval by the members of the Board of the Central Bank. The views and conclusions presented in the papers are exclusively those of the author(s) and do not necessarily reflect the position of the Central Bank of Chile or of the Board members.

Documentos de Trabajo del Banco Central de Chile

Working Papers of the Central Bank of Chile

Agustinas 1180, Santiago, Chile

Teléfono: (56-2) 3882475; Fax: (56-2) 3882231 
Documento de Trabajo

$\mathrm{N}^{\circ} 893$
Working Paper

$\mathbf{N}^{\circ} 893$

\title{
Macroprudential Policy and the Inward Transmission of Monetary Policy: the case of Chile, Mexico, and Russia*
}

\author{
Georgia Bush \\ Banco de México \\ David Moreno \\ Banco Central de Chile
}

\author{
Tomás Gómez \\ Banco Central de Chile \\ Konstantin Styrin \\ The Central Bank of \\ the Russian \\ Federation and New \\ Economic School
}

\author{
Alejandro Jara \\ Banco Central de \\ Chile \\ Yulia Ushakova \\ The Central Bank of \\ the Russian Federation
}

\begin{abstract}
This paper studies whether domestic macroprudential policy may attenuate the inward transmission of monetary-policy shocks from the U.S. to domestic banks' lending growth in three emergingmarket economies -Chile, Mexico, and Russia. Identification relies on banks' heterogeneous exposure to the prudential policies and the fact that foreign monetary policy shocks are exogenous from the perspective of these economies. After analyzing the effects of the aggregate domestic prudential policy stance, we focus on specific prudential policies targeting mortgage and consumer loans, as well as foreign-currency deposits. Although our overall results are mixed, we find evidence that the strength of international monetary policy spillovers varies depending on the stance of the domestic macroprudential policy. In particular, a tighter reserve requirement stance over foreigncurrency deposits in Chile dampens the effect of an international monetary policy shock on domestic local-currency lending, but reinforces that on foreign-currency lending, whereas in Russia, it dampens the effect on both local currency and foreign currency lending, although to different degrees. Prudential policies targeting the asset side of banks' balance sheets, such as mortgage loans or consumer credit, are found to amplify international monetary policy spillovers in some cases and attenuate in others, depending on the country context.
\end{abstract}

\section{Resumen}

Este documento estudia si la política macroprudencial doméstica puede atenuar la transmisión de los shocks de política monetaria de los EE. UU. sobre el crecimiento del crédito de los bancos locales en tres economías emergentes: Chile, México y Rusia. La identificación se basa en la exposición heterogénea que presentan los bancos a las políticas prudenciales y en el hecho de que los shocks de la política monetaria externa son exógenos desde la perspectiva de estas economías. Después de analizar los efectos de la política prudencial interna a nivel agregada, nos enfocamos en políticas prudenciales específicas dirigidas a préstamos hipotecarios y de consumo, así como a los depósitos en moneda extranjera. Aunque nuestros resultados generales son mixtos, encontramos evidencia de

*This research is part of the International Banking Research Network (IBRN) initiative on "Interactions between Macro-prudential and Monetary Policies." We are grateful to the IBRN Methodology Team for providing us with valuable inputs and insights during the first stage of this research project. We are also grateful for comments received from Menzie Chinn, the participants of the July 22nd, 2019 IBRN meeting held at the Federal Reserve Bank of New York, participants of the October 15th, 2019 "IBRN-IMF Workshop on Policy Interactions and International Spillovers in the Global Economy" held in Washington, DC, and two anonymous referee. The usual disclaimer applies. 
que la fuerza del contagio generado por la política monetaria internacional sobre el crédito doméstico varía dependiendo de la orientación de la política macroprudencial interna. En particular, una postura más estricta del requerimiento de encaje sobre los depósitos en moneda extranjera en Chile amortigua el efecto de un shock de política monetaria internacional sobre los préstamos en moneda local, pero lo refuerza sobre los préstamos en moneda extranjera, mientras que en Rusia, amortigua el efecto sobre los préstamos en moneda local y en moneda extranjera, aunque en diferente grado. Además, se muestra que las políticas prudenciales dirigidas a la parte de los activos del balance de los bancos, tales como aquellas que afectan los préstamos hipotecarios o de consumo, amplifican los efectos de contagio de la política monetaria internacional en algunos casos y los atenúan en otros, dependiendo del contexto de cada país. 


\section{Introduction}

In theory, under perfect capital mobility and a free-floating currency regime, foreign-exchange rates adjust to absorb foreign shocks. Thus, we would not expect to find evidence of domestic variables being affected by international shocks in such an economy. Spillovers from foreign monetary policies would be limited, and domestic monetary policy would retain its autonomy. However, in the presence of financial frictions, this may not be the case. Rey (2016) and Rey (2015) find evidence that challenges the Mundellian trilemma, showing that U.S. monetary policy affects prices in many global markets, even under floating-currency regimes. Simultaneously, since the Global Financial Crisis (GFC), the consensus has moved towards the use of "macro" and "micro" prudential policies to strengthen national financial systems' ability to face shocks (Cerutti et al., 2017b; Alam et al., 2019). The domestic and cross-border effects of these prudential policies are part of a burgeoning research agenda, but their interaction with monetary policy remains under-explored.

This paper aims to fill the gap by presenting evidence on the attenuation of international monetary-policy spillovers by domestic macroprudential policies, using confidential data on the balance-sheet exposures of banks in three emerging economies: Chile, Mexico and Russia. We contribute to the currently limited literature on the use of domestic macroprudential tools to curb foreign monetary-policy spillovers into domestic lending.

Foreign monetary policy may affect the domestic supply of banking credit via several channels as has been discussed in the literature. A disruption of bank funding can cause a decrease in loan supply (known as the bank-funding or bank-lending channel) as shown in Kashyap and Stein (2000). A tightening of monetary conditions may require banks to increase reserves and thus reduce deposits. If this is not easily substituted by alternative sources of funds, such as wholesale funding from external markets or internal funding from within the bank's network, banks would adjust their assets and decrease lending.

Monetary-policy spillovers may also occur because of its impact on bank balance sheets, either through valuation effects or revenue effects. For example, interest-rate changes may affect the market value of a bank's holdings of government securities or income from other bank assets. This can lead to portfolio re-balancing which decreases the supply of bank loans (i.e. portfolio channel). ${ }^{1}$ We know from prior research that bank heterogeneity is key to understanding the effects of international monetary-policy spillovers. ${ }^{2}$ Banks may face different financial frictions that prevent a smooth adjustment in response to foreign monetary-policy changes. For example, a bank that relies on short-term foreign funding may be unable to find a substitute if that funding becomes too costly due to monetary-policy changes. Also, the bank's capitalization may determine the intensity of the spillovers if the bank cannot raise capital quickly in response to a negative shock.

Previous research also suggests that monetary spillovers are significant for emerging economies. Using syndicated loan data, Bräuning and Ivashina (ming) shows how the differential between an emerging-market economy policy rate and that of the the U.S. affects the extension of credit to that emerging-market economy, an outward spillover. Key results reported in Buch et al. (2019) show that inward monetary-policy spillovers, the same case we analyze in this paper, were evident in all of the countries included in the meta-study, and that U.S. monetary policy was the dominant core country monetary policy showing spillover effects. Lastly, the spillover effects were more substantial for emerging economies than developed. In particular, Gajewski et al. (2019) show evidence of international monetary policy spillovers to domestic lending in the case of Chile, Korea, and Poland; while Kruglova and Styrin (2017) does the same for Russia. Moreover, studies using credit register data, such as Morais et al. (2019), for the case of Mexico, and Giovanni et al. (2017) and Baskaya et al. (2017) for the case of Turkey, show a negative spillover effect of international financial conditions and capital inflows on domestic bank lending.

In terms of the impact of prudential policies, the state-of-the-art paper on the effects of macroprudential policy is Jiménez et al. (2017). The authors use credit registry data, including loan-application forms, to identify the effects of changes in the dynamic provisioning policy implemented by the Banco de España since

\footnotetext{
${ }^{1}$ An outward spillover may occur as well if an interest-rate increase in a source country leads to the deterioration of the net worth or the collateral values of those borrowers, spurring banks to steer lending towards safer borrowers and borrowers in foreign countries (Correa et al., 2015). As shown in Correa and Murry (2010), a tightening of monetary policy in the U.S., leads to an outward spillover whereby U.S. banks reduce their cross-border claims on (lending to) foreign residents.

${ }^{2}$ See Buch et al. (2019) for a full discussion of the International Banking Research Network (IBRN) project on international monetary-policy spillovers.
} 
Table 1: Country characteristics.

\begin{tabular}{lccc}
\hline & Chile & Mexico & Russia \\
\hline $\begin{array}{l}\text { Total credit to the private } \\
\text { sector/GDP }\end{array}$ & $144 \%$ & $42 \%$ & $64 \%$ \\
$\begin{array}{l}\text { Share of foreign-owned } \\
\text { banks in total assets }\end{array}$ & $40 \%$ & $70 \%$ & $10 \%$ \\
$\begin{array}{l}\text { Share of cross-border lia- } \\
\text { bilities in total assets }\end{array}$ & $27 \%$ & $5 \%$ & $15 \%$ \\
$\begin{array}{l}\text { Share of cross-border as- } \\
\text { sets in total assets }\end{array}$ & $6 \%$ & $5 \%$ & $18 \%$ \\
$\begin{array}{l}\text { Share of loans to private } \\
\text { sector in foreign currency }\end{array}$ & $20 \%$ & N/A & $20 \%$ \\
Year of inflation-targeting & 1999 & 2001 & 2014
\end{tabular}

adoption

Currency regime ${ }^{b}$

Capital mobility $^{c}$

Main prudential-policy interventions
Managed floating: moving band $+/-5 \%$ around the U.S. dollar Managed floating/de
facto moving band +/-
$5 \%$ around the U.S. dollar
De facto crawling band/multiple exchange rates: +/- $2 \%$, later $+/$ $5 \%$ around the U.S. dollar or an euro/U.S. dollar currency basket; large devaluations in 2014-2016

Mortgage policy in 2009 consisting on the increase from $75 \%$ to $100 \%$ on the cap of LTV ratios on mortgage loans granted by notes; FX policy between 2008-2010 consisting on the change in the rules governing the currency of settlement for reserve requirements on $\mathrm{FX}$ bank deposits

\begin{abstract}
"Gate"d
Consumer and mortage related policies consisting on the change in provisioning rules that entailed switching the basis for provisioning requirements from realized losses to expected losses - for credit cards in 2009; and mortgages and non-revolving loans, including payroll loans in 2011
\end{abstract}
FX and consumer related policies. See details in Ta- ble 7 in the Appendix

\footnotetext{
${ }^{a}$ As of 2018. ${ }^{b}$ Classification according to Ilzetzki et al. (2019). ${ }^{c}$ Classification according to Fernández et al. (2016). " "Gate" means that a moderate share of types of cross-border financial transactions are subject to significant capital controls.
}

the end of the 1990s. Regarding the interactions between domestic macroprudential and domestic monetary policy, Gambacorta and Murcia (2017) use credit registry data and find that the two types of policy reinforce each other.

As for the evidence on the interaction between domestic prudential policy and foreign monetary policy, several papers are worth mentioning. Epure et al. (2018) uses credit registry data to study how domestic macroprudential policy interacts with international financial conditions to affect domestic lending in Romania. Takáts and Temesvary (2019) and Avdjiev et al. (2020) study the impact of macroprudential and monetary policy interactions on cross-border lending. These studies emphasize that tighter macroprudential policy in the home country mitigates monetary-policy spillovers, although these results do not necessarily translate to policy interactions affecting domestic credit.

In this paper, we exploit bank-level supervisory data for three emerging economies to analyze whether domestic prudential policies can attenuate the effects of inward monetary-policy spillovers on domestic bank lending.

The three economies of Chile, Mexico, and Russia (CMR thereafter), offer a unique testing ground to analyze international spillovers, as their banking sectors share important features that expose them to a myriad of international shocks, including monetary-policy shocks. Table 1 summarizes characteristics of 
these three economies that are relevant to our study. First, although the three countries vary greatly in terms of their size: Chile, Mexico and Russia represent $0.4 \%, 1.9 \%$ and $3.1 \%$ of world GDP at PPP rates as of 2018, they are all small enough that the monetary policy of core countries can be considered exogenous to developments in their own domestic sectors. ${ }^{3}$

Furthermore, resident banks in CMR have been among the most profitable in the world due to their rapidly developing banking sectors attracting significant foreign direct investment. Indeed, foreign parent banks kept financing their CMR subsidiaries during recent turbulent periods, despite limitations imposed by newly introduced macroprudential regulations (Jara and Cabezas, 2017; Levin-Konigsberg et al., 2017). Banks in CMR provide financial services mainly to domestic borrowers and have limited activity overseas. Nevertheless, their net international investment positions, as depicted in Figure 7, show that the Chilean and Russian resident banking systems meet a significant portion of their funding needs in the international capital markets. Mexican banks show smaller positions. Another notable difference, is in the level of financial deepening, proxied by the ratio of total credit to the private sector to GDP published by the BIS. The Chilean economy has a highly developed domestic credit market, which amounts to $144.4 \%$ of GDP in 2018, compared to a $41.7 \%$ in Mexico and $63.5 \%$ in Russia.

The three countries also vary according to the relevance of foreign-owned banks in domestic credit markets. In Mexico and Chile, the foreign-owned banks represent roughly $70 \%$ and $40 \%$ of total banks' assets, respectively, while in Russia they represent less than $10 \%$, mostly due to the high presence of state-owned banks. In all three economies, the U.S. dollar is the most important foreign currency. The share of banks' foreign liabilities denominated in U.S. dollars in Russia are about $65 \%$ on average. On the asset side, the share of corporate loans denominated in foreign currency is $35-40 \%$ on average, while dollarization of household loans is around $1 \%$. In Chile, around $20 \%$ of domestic loans are denominated in foreign currency, of which the U.S. dollar is the dominant currency. In Mexico, the U.S. dollar has been the predominant currency both for banks' assets and liabilities in foreign currency.

In terms of economic policy, Chile, Mexico and Russia have had formal inflation targeting regimes since 1999, 2001, and 2014 respectively.With respect to currency regime, Ilzetzki et al. (2019) indicate that Chile has had a managed floating regime (a category very close to a free-floating regime) since September 1999. The authors state Mexico has had the same currency regime but with a de facto moving band of $\pm 5 \%$ around the U.S. dollar, since December 2001. Russia, on the other hand, has a currency regime regarded as a de facto crawling band with multiple exchange rates since December 1999, and adopted formally a flexible regime only since November 2014. Given these policy differences, foreign monetary-policy spillovers should be more significant and robust in Russia than in Chile and Mexico during the period analyzed, since the exchange rate absorbs more of the shock the more flexible it is, given a similar stance on capital mobility across borders.

In terms of capital mobility, Fernández et al. (2016) classify all three economies as "gates", meaning they maintain some controls over some types of cross-border transactions. ${ }^{4}$ With respect to the dynamics of capital control policies, Figure 6, based on Pasricha et al. (2018) shows that Russia actively used inflows tightening during the sample period, while Chile and Mexico used mainly outflows easing. Pasricha et al. (2018) emphasizes that policymakers use capital inflows tightening for macroprudential concerns, and capital outflows easing for competitive purposes. ${ }^{5}$

The paper proceeds as follows: Section 2 describes the data and sample used. Section 3 outlines the empirical strategies implemented to analyze the role played by the interaction between domestic prudential policy and foreign monetary-policy changes in the dynamics of domestic banks' credit. Section 4 discusses results, and section 5 concludes with final remarks and directions for future research.

\footnotetext{
${ }^{3}$ World Economic Outlook Database, April 2019.

4 "Gate" countries are neither "walls" nor "open". "Open" countries have, on average, capital controls on less than $15 \%$ ("walls" countries on more than 70\%) of their transactions subcategories over the sample period and do not have any years in which controls are on more than $25 \%$ (less than $60 \%$ ) of their transaction subcategories.

${ }^{5}$ In any case, it is important to distinguish between capital controls and macroprudential policies. As Korinek and Sandri (2016) asserts, the former apply exclusively to financial transactions between residents and non-residents, while macroprudential policy restricts borrowing by domestic agents independently of whether credit is provided by domestic or foreign creditors. Empirical papers on this topic are Frost et al. (2020) and Forbes et al. (2015).
} 


\section{Data and measurement}

In this section we describe the main features and sources of data employed in our study. We combine several quarterly data sets for the 2000-2017 period for Chile, Mexico and Russia. Bank-level outstanding loan volume and balance sheets comes from the former Superintendence of Banks and Financial Institutions ( $\mathrm{Su}$ perintendencia de Bancos e Instituciones Financieras, SBIF) of Chile ${ }^{6}$, the National Banking and Securities Commission (Comisión Nacional Bancaria y de Valores, CNBV) for Mexico, and the Central Bank of the Russian Federation.

Cross-border banking exposures by currency and jurisdiction come from data provided to the Banco Central de Chile (BCCh) by the SBIF, as an input to the balance-of-payments statistics. For Mexico, the data on foreign-currency exposures come from both the monetary authority (Banco de México) and the CNBV. For Russia, information comes from mandatory reports that commercial banks with operations in Russia must submit to the Central Bank of the Russian Federation.

One of the most salient features of the CMR banking systems is a high degree of heterogeneity among their resident banks. Chile and Mexico have very concentrated banking sectors, with a significant presence of foreign-owned banks, particularly in the form of subsidiaries. In contrast, Russia's banking system became more concentrated only after the 2013 reform to its supervision policy.

First, Chilean banks differ in terms of their size, business orientation, and funding structure, among other features. Given the cross-border nature of our empirical exercise, we focus on internationally active banks relevant to domestic markets, i.e. big and medium sized banks as classified by Jara and Oda (2015). ${ }^{7}$ By the end of 2017, this group of banks totaled 10 institutions, 6 domestically-owned, and 4 foreign-bank subsidiaries, and accounted for more than $95 \%$ of total banking sector assets.

In Mexico, the banking sector is also highly concentrated. Seven banks, designated as Domestic Systemically Important banks (DSIBs), account for around $80 \%$ of assets. Fifteen out of 43 banks in operation are domestic affiliates of foreign globally active banks. They vary significantly in terms of size and scope, ranging from banks with limited activity, to some among the largest in the Mexican financial system. Five out of the seven largest banks (65\% of the of the system's assets) are foreign-owned. We focus on the seven DSIBs because of their international linkages and dominance in domestic credit markets.

Lastly, the Russian banking sector has gradually consolidated during the past 20 years. Starting from the last quarter of 2013, the Central Bank of the Russian Federation more than halved the number of operating banks by closing non-viable institutions. This resulted in higher concentration of the banking sector and the predominance of state-owned banks. Starting in 2015, the Central Bank of the Russian Federation prepares an annual list of DSIBs, using three criteria to identify "internationally active" banks. ${ }^{8}$ We selected a subsample of 22 internationally active banks satisfying consistently at least one of the three criteria over the entire sample period 2000-2017, or over the time period the respective institution had operated in Russia.

In our database some banks appear and/or disappear throughout the sample period, resulting in an unbalanced panel. ${ }^{9}$. To account for entry and exit, we adopt different strategies, particularly on mergers and acquisitions Russia relies on constructed merged banks; Chile, on the other hand, accounts for mergers using a binary variable equal to one at the quarter of merger due to having 15 banks. In the case of Mexico, the aftermath of the 1995 "Tequila" crisis shaped the entire structure of the financial system, with an important decrease in the number of banks whether because of going out of business or being merged. Later in the 2000's there was a consolidation phase for the Mexican banking system, and roughly from 2010 and on, the number of banks has increased again. In the case of Russia, the number of banks dropped substantially, especially after the enhancement of supervision policy since 2013, as discussed in the text.

\footnotetext{
${ }^{6}$ Since June 1st, 2019, the SBIF was integrated to the Financial Market Commission (Comisión para el Mercado Financiero or CMF, in Spanish).

${ }^{7}$ In terms of Jara and Oda (2015) bank taxonomy, retail banks are not internationally active, while tesorería banks do not participate in domestic credit markets.

${ }^{8}$ This status applies to a credit institution if, at least, one of the following criteria is satisfied: (1) the credit institution is a parent organization of a banking group with the share of assets allocated to foreign jurisdictions exceeding $10 \%$; (2) foreign liabilities of the bank in question exceed 100 billion rubles, which was equivalent to 1.5 billion U.S. dollars as of 2018; (3) the credit institution belongs to a banking group/a bank holding company with the headquarters located in a foreign jurisdiction.

${ }^{9}$ During the past two decades, CMR economies saw the number of banks drop due to waves of mergers and acquisitions, while foreign banks increased their market share. In the case of Chile, the biggest mergers and acquisitions occurred in the 1990s and early 2000s (Ahumada and Marshall, 2001)
} 


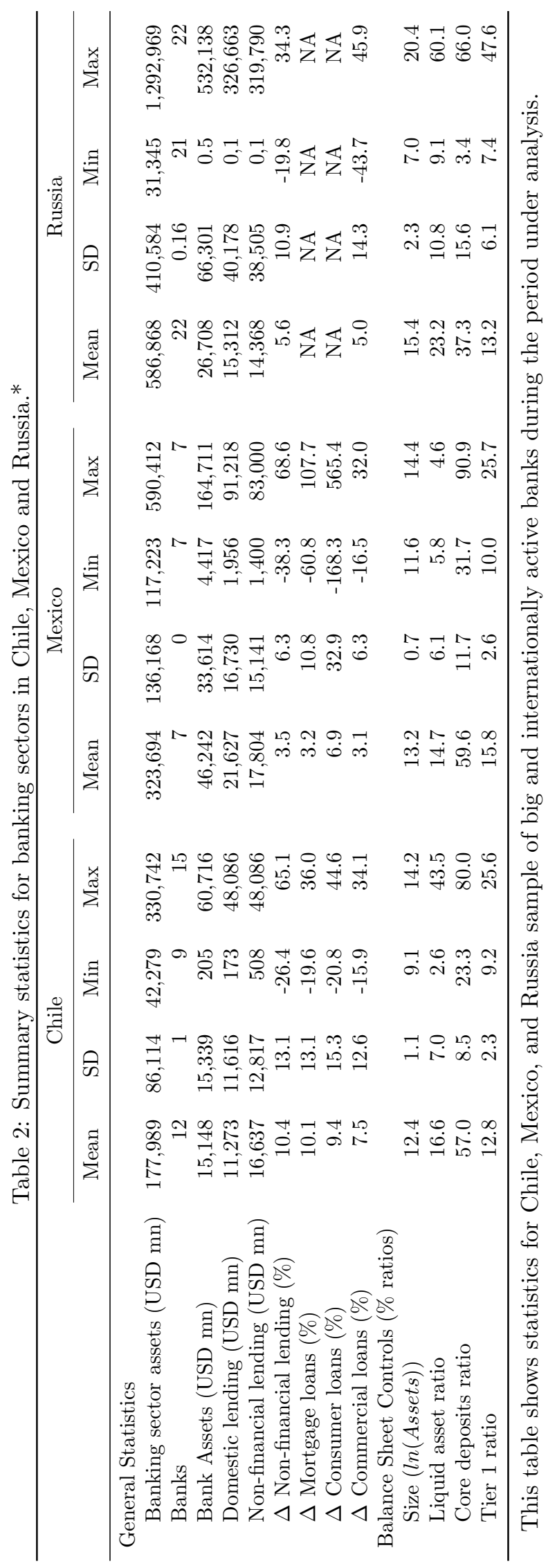




\subsection{Domestic non-financial private-sector credit growth rates}

Exploiting our bank level data, we construct credit growth rates for each bank. Our baseline estimations use the logarithmic quarter-on-quarter change in the outstanding value of a bank's loans to the private sector as the dependent variable. ${ }^{10}$ As robustness checks we also look at loans to different market segments, such as commercial, mortgages, and consumer loans.

We also dis-aggregate loans by currency of denomination: (i) local currency-units, (ii) inflation-adjusted units in the case of Chile, and (iii) foreign currency. The foreign currency loans are adjusted using period average U.S. dollar exchange rates, instead of end-of-period rates, to remove variations due to short-lived currency shocks.

In the case of Russia, the regulatory bank-level data does not provide detailed currency decompositions for loans, and all data are reported in rubles. However, loans are categorized as denominated in rubles or in foreign currency. We assume that all foreign currency loans are in U.S. dollars based on external information that most loans denominated in foreign currency are in U.S. dollars. We employ the end-of-quarter exchange rate of rubles per U.S. dollar to convert the foreign-currency-denominated loans reported in rubles, into U.S. dollars. Ruble-denominated loans are also converted into U.S. dollars. In order to eliminate unwanted valuation effects caused by movements in the rate of U.S. dollars per ruble, we use the sample-period average exchange rate of U.S. dollars per ruble. ${ }^{11}$

\subsection{Bank-level control variables}

A vector of bank balance-sheet characteristics are used as control variables. In particular, we include: (1) a measure of bank size, defined as the log of total assets in constant local-currency units, (2) the share of liquid assets to total assets (liquidity ratio), (3) the ratio of core deposits to total deposits (core-deposits ratio), and (4) the ratio of Tier 1 capital to total risk-weighted assets (capital adequacy ratio). ${ }^{12}$ Bank size proxies economies of scale; the liquid ratio, the capacity of banks to fund additional loans; and lastly, higher core-deposit ratios and capitalization help lower bank funding costs. Table 2 shows the summary statistics of the dependent variable used in our regressions (credit growth rates) for different market segments. It also shows the summary statistics for the control variables.

\subsection{The identification of exogenous monetary-policy movements}

A key concern regarding the measurement of changes in monetary policy is how to address endogeneity in the estimation of our equation (1). To identify a distinct monetary policy effect, we implement two strategies. First, we employ changes in the price of U.S. federal funds futures contract within a 30-minute window around a monetary-policy announcement, which we will refer to as monetary surprises. This method uses high-frequency identification (HFI) and was developed by Gürkaynak et al. (2005). The identifying assumption is that within this short time period, the monetary-policy announcement is the only news that economic agents learn and therefore, the sole cause of asset price movements. For this paper, we will use the current-month futures contract for the U.S. Fed funds rate, and will henceforth refer to this monetary-policy proxy as "MP1".

In our second strategy, we follow closely Gertler and Karadi (2015) and use the monetary surprises as external instrumental variables (Mertens and Ravn, 2013; Stock and Watson, 2012) to identify monetarypolicy shocks within an SVAR framework. The logic is that a systematic component of the surprise may be interpreted as a monetary-policy shock because it will be free of noise due to market over- or under-reaction and relates solely to monetary-policy changes that are exogenous to macroeconomic conditions. The shock series is obtained by first estimating a monthly four-variable twelfth-order SVAR including the consumer price index, the industrial production index, the one-year nominal interest rate on government bonds (the

\footnotetext{
${ }^{10}$ For the case of Chile and Mexico, this includes interbank lending, but it represents a negligible fraction of banking credit volumes. For Russia, we focus only on loans to private non-financial borrowers.

${ }^{11}$ To deal with outliers, we apply a $1 \%$ winsorisation to our data and drop observations whose effective credit growth rates are either above 100 or below -100 .

${ }^{12}$ In the case of Russia, the definition of the Tier 1 capital ratio has changed several times over the sample period. For that reason, we use the inverse of the leverage ratio as a substitute, which is defined as the ratio of the bank's capital to its (unweighted) total assets.
} 


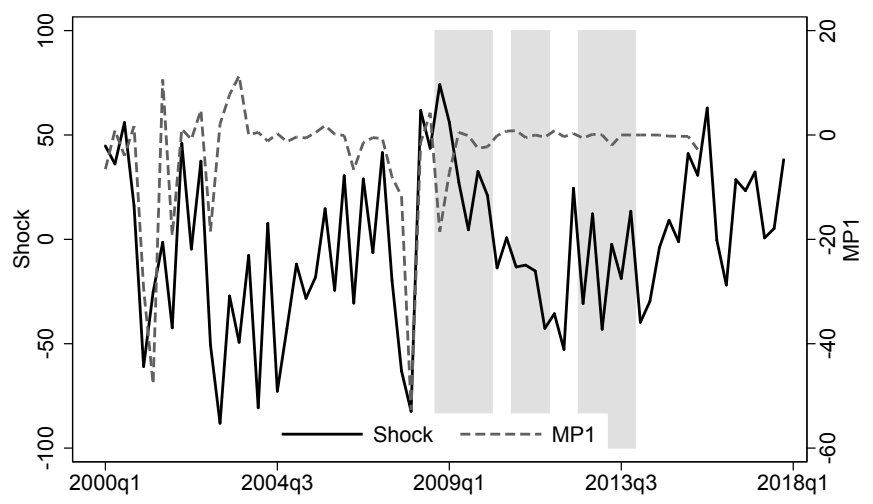

Figure 1: U.S. monetary-policy shock and surprise (both in units). These figure shows the U.S. monetarypolicy shock and surprise series. Shaded areas indicate Fed Quantitative Easings (QE1, QE2, and QE3). Source: Authors' elaboration.

monetary-policy indicator), and the excess bond premium (EBP) of corporate bonds from Gilchrist and Zakrajšek (2012). Each variable's reduced-form VAR innovation, which is the residual from an OLS regression of this variable on its own lags and those of the other variables, is assumed to be driven by exogenous structural shocks, where one of them is the monetary-policy shock. To the extent that the monetary-policy shock is the only structural shock that gives rise to monetary surprises, an OLS projection of the monetary surprises on the space spanned by the reduced-form VAR innovations will isolate the structural monetarypolicy shock.

Figure 1 shows the series of U.S. monetary-policy surprises and structurally identified shocks used in our empirical analysis. The chart highlights key differences between shocks and surprises. In particular, during the era of unconventional monetary-policy. We show results with both measures in order to relate to the literature on monetary-policy shock identification.

\subsection{The stance of domestic prudential policy}

Emerging-market economies have usually relied on prudential tools for longer and more often than advanced economies (Cerutti et al., 2017a; Bank for International Settlements, 2019; Alam et al., 2019), mainly due to their past history of banking crises. However, in many cases, these policies have remained unchanged over time. This is precisely the case in Chile and Mexico, where only a few changes in prudential policy occurred during the sample period. In particular, Mexico experienced three changes during the time period under study: concentration and interbank exposure rule changes in 2003, capital requirements for Basel 2.5 in early 2012 and Basel 3 in late 2012. These were measures taken to fortify the existing prudential policy framework rather than reactions to a particular credit dynamic. In contrast, the Russian Federation has relied strongly on prudential policy changes, which include the increase of required reserve ratios for credit institutions' liabilities to non-resident banks several times, in order to limit negative consequences of growing dependence on external funding sources. ${ }^{13}$ Russia also implemented policies targeting a boom in the unsecured consumer lending market ${ }^{14}$, and the increased volatility in financial markets. ${ }^{15}$ Finally, the

\footnotetext{
${ }^{13}$ Starting in October 2006 , this ratio increased from $2 \%$ to $3.5 \%$, and reaching $8.5 \%$ by the 1 st of September 2008. Beginning on the 18th of September 2008, following the Lehman Brothers bankruptcy and with deteriorating bank liquidity, the requirement was reduced, reaching $0.5 \%$ in October 2008, along with substantially reduced required reserve ratios for all categories of liabilities.

${ }^{14}$ March 2013, Russia doubled loan-loss provisions for unsecured consumer loans without overdue payments and with overdue payments of 1 to 30 days; July 2013 it raised risk weights for consumer loans, depending on the currency of the loan and its total cost. Later, on January 2014, Russia again raised loan-loss provisioning requirements for unsecured consumer loans and their risk weights.

${ }^{15}$ In the second half of 2014, the Central Bank of the Russian Federation took measures to restrain high levels of dollarization in the banking sector. These were aimed at both the asset and liability sides of the banking sector's balance sheet. In 2015, risk weights for foreign currency claims on the household sector were increased, as well as for foreign currency loans to corporate entities for use for real-estate purchases or whose foreign exchange earnings were insufficient to service their debt obligations; a similar measure was applied to investments in foreign-currency securities.
} 

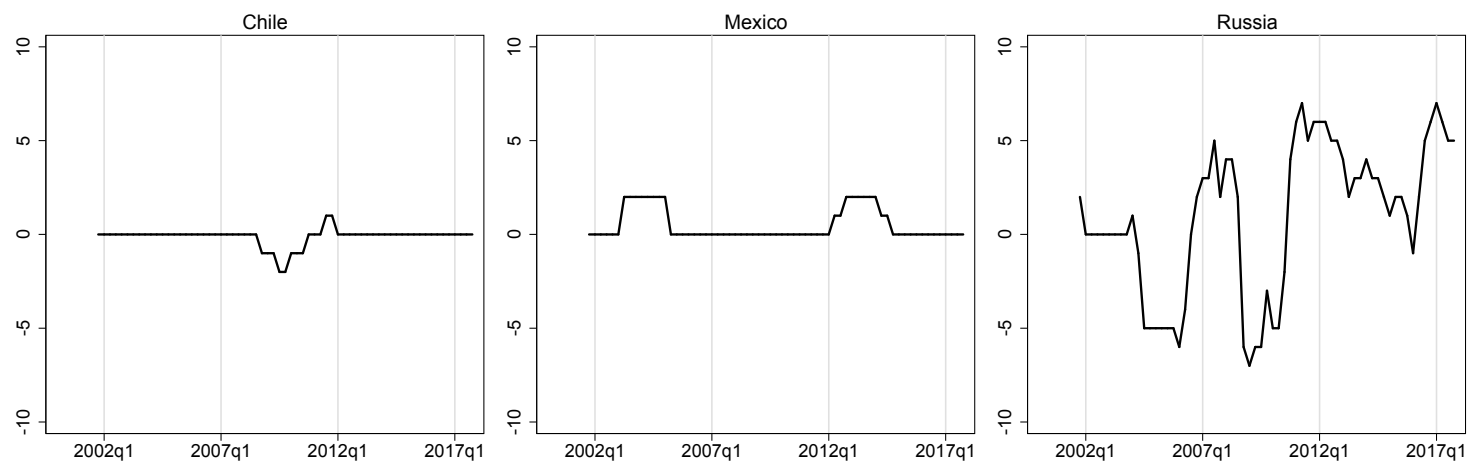

Figure 2: Aggregate prudential policy stance for Chile, Mexico, and Russia. The figure shows the 2-years cumulative aggregate PruP index. Sources: Cerutti et al. (2017b).

Central Bank of the Russian Federation increased risk weights several times during 2017 and 2018, related to an ongoing boom in household credit. It also increased risk weights for ruble mortgage loans with a high LTV (>90\% and from 80 to $90 \%$ ) in order to discourage banks from issuing loans with low down payments. ${ }^{16}$

To study the role played by domestic prudential policy in the transmission of global monetary-policy spillovers into the banking sector, it is essential to be able to capture periods of different policy stances. To do so, we follow two approaches for all three countries. First, we use an aggregate measure of the domestic prudential policy stance, based on a 2-year cumulative prudential index constructed by Cerutti et al. (2017b) updated until 2017 Q4, which is shown in Figure 2. Second, we study the role played by prudential policies that targeted specific credit segments, such as mortgage loans or consumer credit, and those focused on the funding side of banks' balance sheets. Some countries used these actively, while others implemented one-off changes.

Regarding specific prudential policies, we study the significance of two policies for each country. In the case of Chile, these policies are: (1) the increase from $75 \%$ to $100 \%$ on the cap of loan-to-value (LTV) ratios on mortgage loans granted by mortgage notes (letras de crédito) in August 2009, and (2) a change in the rules governing the currency of settlement for reserve requirements on foreign-currency bank deposits. The latter policy was implemented in October 2008 and reversed in February 2010, added the yen and the euro as currencies allowed to settle foreign-currency deposits reserve requirements (usually, only the U.S. dollar is authorized).

In the case of Mexico we study the change in provisioning rules implemented under the transition to the International Financial Reporting Standards (IFRS) 9, issued by the International Accounting Standards Board. This change entailed switching the basis for provisioning requirements from realized to expected losses, and can be considered exogenous to financial and real conditions. In particular, we will focus on two sectors where this change was implemented: (1) credit cards, implemented in October 2009, and (2) mortgages and non-revolving loans, including payroll loans, implemented in March 2011. ${ }^{17}$ These policy changes may have been expected to tighten conditions given that banks would need to incorporate a forward-looking component of loan loss provisioning. However, there is no clear evidence that this was the case. Figure 11 shows the loan-loss provisioning for mortgages before the rule change, which was based on past delinquency, and therefore closely tracks the delinquency rate (non-performing mortgage loans). However, leading up to the rule change (the vertical line), we see that the provisioning rate in fact decreased to below the delinquency rate. Although we do not have similar data for the credit-card sector, the mortgage case illustrates that we should not assume that the IFRS-9 rule changes were necessarily de facto tightening.

\footnotetext{
${ }^{16}$ For a detailed description of the prudential policies undertaken recently in Russia, see table 7 in the Appendix, taken from Danilova and Morozov (2017).

${ }^{17}$ It is important to notice that the prudential-policy changes from IFRS-9 were exogenous to credit cycle conditions and one-off: banks knew they would not be reversed. However, plans for general convergence to IFRS-9 were communicated as early as 2008, and it was known that various sectors would be targeted. The law took effect in the third quarter of 2009 for credit cards, one of the first sectors to be targeted, and the first quarter of 2011 for mortgages. It could be possible that banks had already adjusted their behavior in anticipation of the application of mortgage-sector regulatory changes
} 
Finally, in the case of Russia, the first policy relates to the foreign-currency funding of Russian banks The Central Bank of the Russian Federation used reserve requirements for liabilities to non-residents, to curb unwanted capital inflows, for the first time during 2006-2008 and later in 2011 and 2016. In all episodes, the policy intervention was intended to increase the resilience of the banking sector by reducing the likelihood of accumulation of risks due to currency mismatches between banking assets and liabilities. The second prudential policy pertains to consumer credit, which was targeted by the Central Bank of the Russian Federation after 2013 and in 2018. Risk weights were increased for high-interest unsecured loans, which were perceived as too risky. For this policy, we construct a 2-year cumulative sub-index of Cerutti et al. (2017b) that captures only prudential policies targeting consumer credit.

\subsection{Banking exposure to policies}

Ideally for identification, we would prefer prudential policies that vary at the bank level. However this is not often the case. Exploiting our bank balance sheet data, we construct measures of individual bank's exposure to the domestic prudential policies, and/or foreign monetary policy. A first group of measures seeks to capture spillovers via banks' foreign-funding mechanisms and their related domestic prudential polices. In the cases of Mexico and Russia, the banks' amount of funding from abroad as a percent of total liabilities (NRL/TL); for Chile, the variable is a banks' foreign-currency deposits as percentage of total assets.

A second group of measures attempts to proxy a bank's exposure to the individual prudential policy stances described above. In the case of Chile, for changes in LTV we use mortgage notes (letras de crédito) as a percentage of total mortgage loans (MN/ML). To measure banks' exposure to changes in foreigncurrency deposits reserve requirement, we take the total foreign-currency deposits as a share of total assets (FCD/A). Figure 3 shows the banks' distribution of these channels over the sample period, before and after the prudential policy change, which is indicated with a vertical solid line. Figure 3 on the left shows a systematic decrease in mortgage notes as a share of mortgage lending, with a slight deceleration after the LTV limit increases (a prudential policy loosening) by the end of 2009. Figure 3 to the right, on the contrary, shows that the share of foreign-currency deposits was increasing before the change in foreign-currency deposit reserve-requirement policy; the first vertical solid line represents the initial loosening in the prudential policy, while the second represents a tightening (which is the reversal of such policy).

For the case of Mexico, bank sensitivity to the domestic prudential policy is measured by the exposure to the credit sector targeted by the prudential policy. Figure 4 depicts the evolution of the distribution of banks' credit-card assets to total assets (CC/TL). The upper part of the distribution shows that some banks are highly specialized in the credit card sector. For housing credit, the left panel of Figure 4 shows the quarterly distribution of bank mortgage assets to total assets (ML/TL). Several banks competed to expand their mortgage portfolios in the latter part of the sample. Mortgages are concentrated within some of the largest banks in the system. As illustrated, both of these bank-exposure variables vary over time and across banks.

For Russia, as a proxy for the exposure of a bank to reserve requirements on foreign liabilities, we use the ratio of non-resident liabilities to total liabilities (NRL/TL). Secondly, the ratio of consumer loans to total assets (CL/TL) serves as a proxy to the exposure to the prudential policy targeting this credit segment. The distributions of both variables across banks and time are shown in Figure 5.

It is worth mentioning that the measurement of these exposures is also challenging because in some cases the prudential policy may be targeting the same mechanisms. For example, when focusing on the portfolio channel of monetary policy, we would like to measure the potential for foreign monetary policy to affect bank interest income and the market value of bank assets through the foreign interest rate changes or the exchange-rate adjustment. For example, looking at the U.S. monetary-policy spillovers, we need a measure of the domestic bank's debt securities or gross assets denominated in U.S. dollars, or associated with the U.S. non-financial private sector. A tightening of U.S. monetary-policy would increase the interest rates in the U.S. and potentially strengthen the U.S. dollar, which would in turn affect more domestic banks with a higher share of these assets in their balance sheets. For a lending-channel spillover effect, we would like to measure bank's exposure to foreign funding, gross liabilities or deposits from abroad. Foreign monetary-policy could affect domestic banks' cost of and access to this funding source.

Depending on the prudential policy being considered, the exposure measure may be capturing the sensitivity to both foreign monetary policy and domestic prudential policy. For example, foreign-currency 

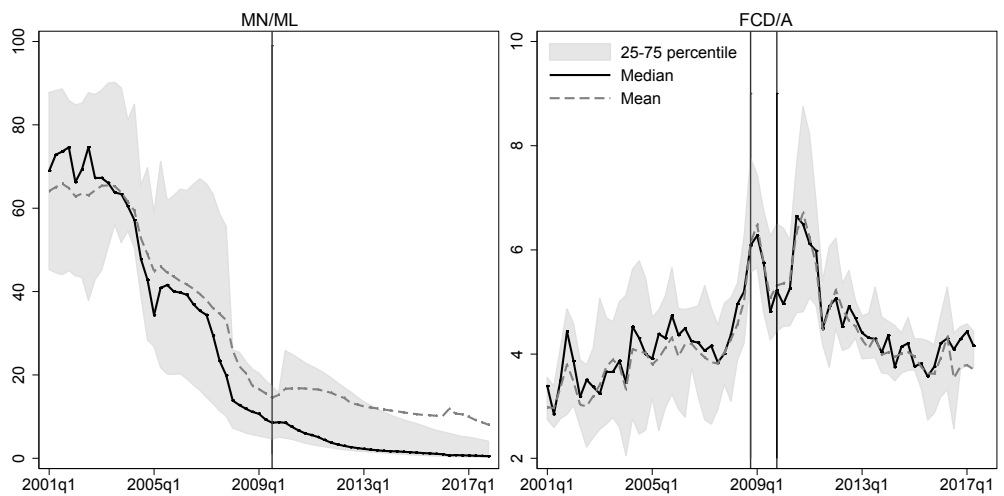

Figure 3: Chilean banks' exposure to LTV change of mortgage notes and reserve requirements for foreigncurrency deposits. These figures show the distribution of the transmission channels for LTV and reserve requirements policy changes between 2000 and 2017. The vertical lines represents policy changes: a loosening of domestic LTV in 2009q3, and a loosening and subsequent tightening in the local foreign-currency deposit reserve requirement in 2008q4 and 2009q4 respectively. Source: Authors' elaboration.

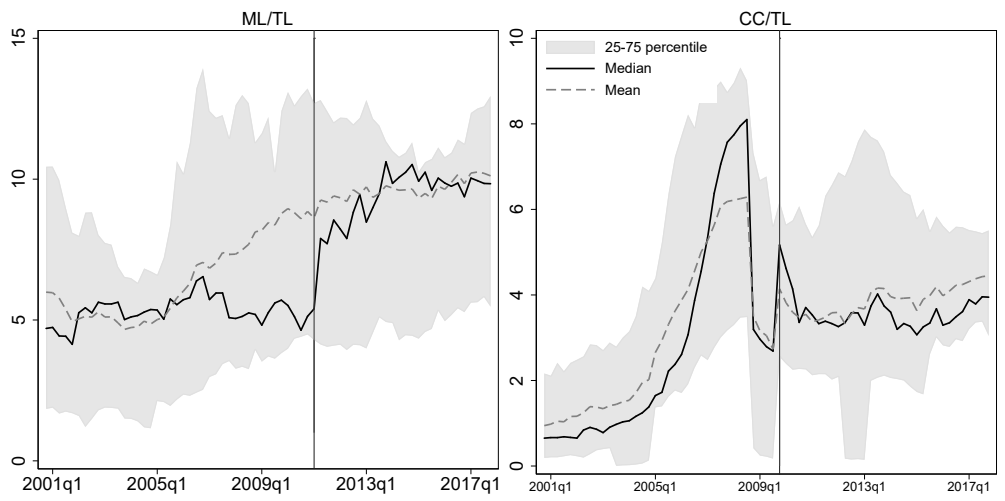

Figure 4: Mexican banks' exposure to mortgage and credit cards provisioning changes. These figures show the distribution of the transmission channels for mortgage and credit cards provisioning changes between 2000 and 2017. The vertical lines represents the policy changes: a change of mortgages provisioning rule in 2011q1, and a change in credit cards provisioning in 2009q4. Source: Authors' elaboration.

prudential policies are aimed at protecting banks from foreign funding shocks. Thus the share of foreign liabilities to total liabilities may capture both sensitivity to foreign monetary and domestic prudential policy. Other exposure measures are more directly aligned with the bank's sensitivity to domestic prudential policy. For example, domestic-LTV prudential policy targets the domestic mortgage sector, and a bank's share of mortgage assets in total assets will be a measure of the exposure to that specific prudential policy.

The advantage of using these exposure measures, is that these variables are heterogeneous across banks, which enables the estimation of the effects of the interaction between foreign monetary-policy shocks and the stance of domestic prudential policy on bank level credit growth, whilst controlling for bank and time fixed effects.

\section{$3 \quad$ Empirical strategy}

This section presents the empirical strategy we follow to analyze the role of monetary and prudential policy interactions. In particular, we focus on whether the domestic prudential policy stance shields local banks' credit markets from international monetary-policy spillovers.

The starting point of our analysis draws on existing empirical evidence of international monetary-policy 


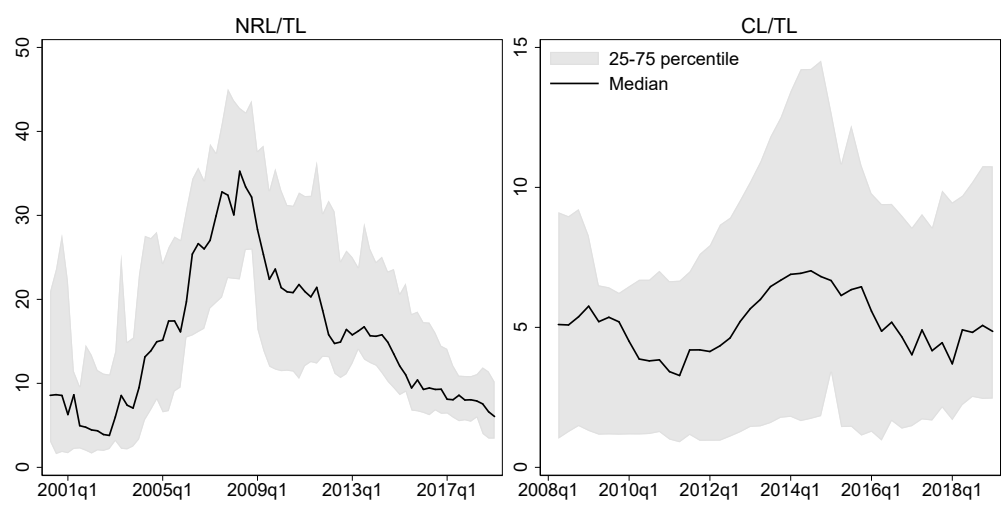

Figure 5: Russian banks' non-residents liabilities and consumer lending. These figures show the distribution of banks' exposure to the domestic prudential policy stance. The left panel shows the non-resident liabilities to total liabilities (NRL/TL), while the right panel shows the consumer lending to total lending (CL/TL). Source: Authors' elaboration.

spillovers into domestic bank lending for Chile, Mexico, and Russia. As mentioned previously, Gajewski et al. (2019), Morais et al. (2019), and Kruglova and Styrin (2017) show negative inward spillovers for the case of Chile, Mexico, and Russia, respectively. It is important to note, however, that the monetary policy variables and channel analyzed in these studies differ from those considered here, making direct comparison difficult. As such, we implement a simple specification using our sample and bank-level data for each country, to capture direct foreign monetary-policy inward spillovers into domestic bank lending. We do so by looking at the interaction between our monetary policy variables and bank exposure variable, controlling for time and bank fixed effects. We consider the two monetary-policy shocks described earlier, and the exposure to foreign currency funding as the transmission channel. This estimation is performed over rolling windows to observe the time variation in the estimated inward spillover effect. Figure 8 in the Appendix shows these results. For both proxies of the exogenous monetary-policy changes, we see notable variation over time in the case of Mexico and Russia - even the sign of the spillover changes at some points. In the case of Chile, the effect is almost zero. We argue that this is consistent with the evolution of the exchange rate regimes in all three countries described above. Further, the inspection of these graphs suggests that the strength of the inward transmission tends to decline when domestic prudential policy tightens, in particular for the case of Russia, where macroprudential policy has been used more actively. Since the prudential policy stance has varied during this period, we argue this may be the cause of the time variation in the estimated effect of foreign monetary-policy shocks on domestic credit. This begets the critical question of our paper: may domestic prudential policy attenuate inward monetary-policy spillovers?

To answer this question, we run the following specification.

$$
\begin{aligned}
\Delta y_{b, t}= & \alpha_{0}+\sum_{c=1}^{C} \sum_{k=0}^{K} \alpha_{1, k}^{c} \Omega_{b, t-K-1} \Delta M P_{t-k}^{*}+\alpha_{2} \Omega_{b, t-K-1} \operatorname{Pru}_{t-K-1}^{d}+ \\
& \sum_{c=1}^{C} \sum_{k=0}^{K} \alpha_{3, k}^{c} \Omega_{b, t-K-1} \operatorname{Pr}_{t-K-1}^{d} \Delta M P_{t-k}^{*}+\alpha_{4} \Omega_{b, t-K-1}+\alpha_{5} \mathbf{X}_{b, t-1}+f_{b}+f_{t}+\varepsilon_{b, t}
\end{aligned}
$$

where $\Delta y_{b, t}$, is quarter-on-quarter growth in domestic bank credit for bank $b$ in quarter $t$. Since we analyze prudential policies that are homogeneous across all banks within the same jurisdiction $\left(\operatorname{Pru}_{t}^{d}\right)$, we use banks' exposure to prudential policy or foreign monetary policy $\left(\Omega_{b, t}\right)$ to account for bank heterogeneity in the identification strategy. Thus, in this model we use the triple interaction term to identify whether prudential policy modifies the impact of foreign monetary policy.

For the changes in U.S. monetary policy $\left(\Delta M P_{t}^{*}\right)$ we use two measures, as mentioned earlier: monetarypolicy surprises, which are derived from the price of the money market interest rate futures contracts, and a monetary-policy shock identified within a structural vector autoregression (SVAR) framework.

Note that the two sets of coefficients of interest are $\alpha_{1, k}^{c}$ and $\alpha_{3, k}^{c}$. The first captures the foreign monetary- 
policy spillover from a given country $c$ lagged $k$ quarters, i.e. $\Delta M P_{t-k}^{c}$, on domestic banks' lending from bank $b$ in period $t$, through the interaction with a measure of the bank's pre-existing exposure $\Omega_{b, t-K-1}$ to either foreign monetary policy or domestic prudential policy. The second, $\alpha_{3, k}^{c}$, captures the impact of the foreign monetary policy interacted with the domestic prudential policy stance prior to the foreign monetary-policy actions Pru $u_{t-K-1}^{d}$, again using the time varying bank-specific policy exposure measure $\Omega_{b, t-K-1}$. Therefore, the first coefficient could be seen as the spillover when $\operatorname{Pr} u_{t-K-1}=0$, while the second will be the differentiation term for active prudential policy periods. We set $K$ equal to three, so $k \in\{0,1,2,3\}$ captures the impact of changes in monetary policy contemporaneously and up to three lags. We also include $\mathbf{X}_{b, t-1}$ which is a vector of lagged control variables for bank-specific characteristics; $f_{b}$ and $f_{t}$ for individual-bank and time fixed effects, respectively. Finally, $\varepsilon_{b, t}$ corresponds to the error term.

We expect a tightening in the United States to have contractionary effects on domestic credit, a negative sign for the cumulative monetary-policy coefficient estimates. Our hypothesis is that prudential policy has an offsetting effect, either completely offsetting the spillover or attenuating the spillover (a positive sign). The estimated effect of foreign monetary policy may be imprecise due to the challenges of measuring monetary policy, and analyzing its impact. As discussed, several monetary-policy proxies have been used in the literature and the evidence of international spillovers varies depending on the proxy used and whether for a period of conventional or unconventional monetary policy. These proxies may capture different types of information than just the monetary-policy stance alone, and these in turn can drive agents' behavior in different ways. For example, an increase in the U.S. monetary-policy shadow rate or a monetary-policy surprise measure may be seen as a sign of an economic boom, promoting credit creation. Also, as emphasized in Bussière et al. (ming) and Buch et al. (2019), country specific factors can result in either a positive or negative spillover. ${ }^{18}$

\section{Results}

First, we look at the role played by the aggregate policy stance measured by cumulated changes (tightening and easing) over a 2-year period, as described above. Second, we analyze the role played by policies targeting banks' deposits in foreign currency, such as those implemented in Chile and Russia. Third, we look at the role of LTV and mortgage provisioning policies, as implemented in Chile and Mexico respectively. Finally, we analyze the case of Mexico and Russia regarding the role of prudential policies targeting consumer credit.

Our benchmark results are presented for two proxies for U.S. monetary-policy actions: the SVAR identified structural U.S. monetary shock and the monetary surprise (MP1). ${ }^{19}$ In general, we hypothesize that foreign monetary-policy actions will have an impact on the domestic credit cycle in countries like Chile, Mexico, and Russia given the presence of financial frictions, which could be offset by the stance of prudential policies.

\subsection{The role of the aggregate prudential policy stance}

The first row in Table 3 shows the impact of a monetary-policy tightening in the United States on domestic credit growth rates, conditional on banks' exposure to foreign funding. We find some evidence of inward monetary-policy spillovers in Russia as hypothesized: for the shock series the coefficient estimate is significant and negatively signed. However for Chile and Mexico, the effects are statistically insignificant except in the case of Mexico for the surprise series where the estimated direct spillover is actually positive.

A possible explanation for this, is the fact that FOMC meetings may not only deliver monetary-policy shocks to the financial markets, but also information regarding the Fed's outlook on economic activity (Jarociński and Karadi, 2020; Miranda-Agrippino and Ricco, ming). When the interest rates are raised due to a better than expected economic outlook by the Fed, financial markets can take that as a positive shock, muddling the impact of the monetary-policy tightening shock that may occur simultaneously. Due to the tight trade linkages between Mexico and the United States, these positive "central bank information" shocks may be well transmitted to the Mexican banking system.

\footnotetext{
${ }^{18}$ If the spillover is positive, a foreign monetary-policy tightening increases domestic credit growth and our hypothesis would be that domestic prudential policy lessens this spillover effect.

${ }^{19}$ Results assessing the joint impact of the U.S., the euro-area, and the U.K. monetary-policy changes are available from the authors upon request.
} 
Table 3: U.S. $M P$ spillovers, 2-year cumulative changes in domestic prudential index.

\begin{tabular}{|c|c|c|c|c|c|c|}
\hline \multirow[b]{2}{*}{$\begin{array}{l}\Delta M P^{U S} \\
\Omega\end{array}$} & \multicolumn{2}{|c|}{ Chile } & \multicolumn{2}{|c|}{ Mexico } & \multicolumn{2}{|c|}{ Russia } \\
\hline & $\begin{array}{c}\text { Shock } \\
\text { FCD/TL }\end{array}$ & $\begin{array}{c}\text { MP1 } \\
\text { FCD/TL }\end{array}$ & $\begin{array}{c}\text { Shock } \\
\text { NRL/TL }\end{array}$ & $\begin{array}{c}\text { MP1 } \\
\text { NRL/TL }\end{array}$ & $\begin{array}{c}\text { Shock } \\
\text { NRL/TL }\end{array}$ & $\begin{array}{c}\text { MP1 } \\
\text { NRL/TL }\end{array}$ \\
\hline$\sum_{k=0}^{K} \Omega_{b, t-K-1} \times \Delta M P_{t-k}^{U S}$ & 0.00 & -0.04 & -1.08 & $0.06^{* *}$ & $-0.22^{*}$ & 0.39 \\
\hline $\bar{\Omega}_{b, t-K-1} \times \operatorname{Pr} u_{t-K-1}^{d}$ & 1.56 & $-2.20^{* *}$ & -0.06 & 0.34 & $-0.01^{* *}$ & $-0.02^{* * *}$ \\
\hline$\sum_{k=0}^{K} \Omega_{b, t-K-1} \times P r u_{t-K-1}^{d} \times \Delta M P_{t-k}^{U S}$ & 0.11 & $6.32^{* * *}$ & -2.69 & 0.12 & $0.07^{* *}$ & -0.15 \\
\hline$\Omega_{b, t-K-1}$ & -0.16 & 0.27 & -0.45 & -0.35 & -0.05 & -0.00 \\
\hline Obs. & 706 & 614 & 196 & 196 & 1265 & 1054 \\
\hline No. of banks & 13 & 13 & 7 & 7 & 22 & 22 \\
\hline$R^{2}$ & 0.44 & 0.49 & 0.23 & 0.23 & 0.28 & 0.22 \\
\hline
\end{tabular}

Noets: The dependent variable is log-changes of loans to the domestic non-financial private sector, for all currencies. The data are quarterly from 2000Q1 to 2017Q4 for a panel of all resident banks with foreign exposures. $\triangle M P^{U S}$ refers to the SVAR identified structural U.S. monetary shock (Shock) or the monetary surprise (MP1) defined in Subsection 2.3. The measure of exposure $\Omega_{b, t}$ corresponds to foreign-currency deposits to total liabilities (FCD/TL) in the case of Chile, and non-residents liabilities to total liabilities (NRL/TL) for Mexico and Russia. All specifications include the set of control variables $X_{b, t}$, as well as time and banks fixed effects. Standard errors are robust to cross-sectional dependence in panel estimation. ${ }^{* * *},{ }^{* *}$, and $*$ indicate significance at the $1 \%, 5 \%$, and $10 \%$ level, respectively.

The second row shows bank sensitivity to the aggregate prudential policy stance. In the case of Russia, the interaction between the bank exposure to foreign funding and the stance of domestic prudential policy is significant and negative in both specifications, meaning banks with a higher proportion of non-resident liabilities slowed credit growth in response to prudential tightening. ${ }^{20}$

Table 3 provides limited evidence that the aggregate domestic prudential-policy stance offsets U.S. monetary-policy spillovers. The third row represents the coefficient estimates for the triple interaction, capturing the amplifying or attenuating effect of the overall domestic prudential policy stance on inward monetary policy spillovers. Although the coefficients on the triple-interaction term change signs depending on the monetary-policy measure, they are only statistically significant in the case of Chile and Russia. In these countries, a tight aggregate prudential-policy stance appears to offset international monetary-policy spillovers, as the coefficient of the triple interaction is positive and statistically significant at $1 \%$ when the monetary-policy action is proxied by the MP1 in the case of Chile and by the SVAR-shock in the case of Russia.

These results are inconclusive regarding the question of whether the overall domestic prudential policy stance attenuates the effect of foreign monetary-policy shocks on domestic lending. In what follow, we analyze the effect of specific prudential policies.

\subsection{The role of prudential policies targeting foreign-currency reserve require- ments}

Table 4 shows the results for the case of Chile and Russia when considering foreign-currency reserve requirements as the specific prudential policies and the corresponding measure of bank exposure to such policies. The table reports results using the U.S. monetary policy shock series, whereas results for the surprise series are shown in Appendix 8. We split the effect on credit cycles by currency composition, between local-currency (Chilean pesos and Russian rubles, respectively), and foreign-currency loans. In particular, the role of monetary and prudential policy interactions are highlighted in the third row, where we show whether U.S. monetary-policy spillovers into domestic lending are affected by the stance of the prudential policy.

In Chile, banks' exposed to a tight reserve-requirement prudential policy stance react differently to international monetary-policy shocks, depending on the loans' currency denomination. Our results show

\footnotetext{
${ }^{20}$ In the Russian case, using the point estimate from the specification with the shock monetary-policy proxy, for a median internationally active Russian bank with foreign liabilities of $15 \%$ of total liabilities, an unanticipated monetary easing in the United States by 0.25 p.p. increases the bank's lending growth rate by 0.8 p.p. over a one-year horizon.
} 
Table 4: Chile \& Russia: U.S. MP SVAR shock under foreign-currency reserve-requirement policy stance.

\begin{tabular}{lccccc}
\hline & \multicolumn{2}{c}{ Chile } & & \multicolumn{2}{c}{ Russia } \\
\cline { 2 - 3 } \cline { 5 - 6 }$\Omega$ & FCD $/ \mathrm{A}$ & FCD/A & & NRL/TL & NRL/TL \\
Loans & LC & FC & & LC & FC \\
\hline$\sum_{k=0}^{K} \Omega_{b, t-K-1} \times \Delta M P_{t-k}^{U S}$ & 0.00 & -0.00 & & $-0.24^{* *}$ & $-0.40^{* * *}$ \\
$\Omega_{b, t-K-1} \times P r u_{t-K-1}^{d}$ & $-0.73^{* * *}$ & $0.43^{* * *}$ & & $-0.04^{* *}$ & -0.03 \\
$\sum_{k=0}^{K} \Omega_{b, t-K-1} \times P r u_{t-K-1}^{d} \times \Delta M P_{t-k}^{U S}$ & $0.03^{* * *}$ & $-0.01^{* * *}$ & & 0.10 & $0.19^{* * *}$ \\
$\Omega_{b, t-K-1}$ & 0.00 & -0.01 & & 0.00 & -0.07 \\
\hline Obs. & 782 & 785 & & 1265 & 1265 \\
No. of banks & 15 & 15 & & 22 & 22 \\
$R^{2}$ & 0.54 & 0.43 & & 0.25 & 0.21 \\
\hline
\end{tabular}

Notes: The dependent variables are log-changes in loans to the domestic non-financial private sector, in local or foreign currency. The data are quarterly from 2000Q1 to 2017Q4 for a panel of all resident banks with foreign exposures. In this case, we only present results using the SVAR identified structural for U.S. monetary shock (Shock), as $\Delta M P^{U S}$ measure. Outcomes related to the monetary surprise (MP1) are shown in appendix 8 . The measure of exposure $\Omega_{b, t}$ corresponds to deposits in foreign currency as $\%$ of total assets (FCD/ALC) in the case of Chile, and non-residents liabilities over total liabilities (NRL/TL) in the case of Russia. All specifications include the set of control variables $X_{b, t}$, as well as banks and time fixed effects. Standard errors are robust to cross-sectional dependence in panel estimation. ${ }^{* * *},{ }^{* *}$, and $*$ indicate significance at the $1 \%, 5 \%$, and $10 \%$ level, respectively.

a positive and statistically significant effect on local-currency denominated loans, but a negative effect for foreign-currency denominated loans. These effects are statistically significant at $1 \%{ }^{21}$ We interpret these results as a substitution effect between foreign and local currency loans. In other words, banks that hold relatively higher foreign-currency denominated deposits increase their total domestic lending as a result of a tighter monetary-policy surprise when the stance of the prudential policy is also tight.

In the case of Russia, initially we emphasize the effect of the SVAR identified U.S. monetary shock in the first row of Table 4, which shows a negative, statistically and economically significant spillover into both local currency and foreign currency loans. ${ }^{22}$ However, the triple interaction shown in the third row calls for an offsetting effect of the prudential policy targeting bank funding in foreign currency. In the case of loans in rubles, this effect is statistically insignificant. The impact in the case of foreign-currency denominated loans, however, is positive and statistically significant. ${ }^{23}$

It is conceivable that prudential policies implemented in Russia other than foreign-currency reserve requirements, also influenced the incentives of domestic banks to borrow in foreign currency. To address this possibility, we analyze the impact of the 2-years cumulative aggregate prudential index on the credit cycle split by currency denomination. The results presented in Table 8 in the Appendix show that the currency breakdown of loans in specifications with the MP1 show a pronounced effect of U.S. monetary shocks on lending for foreign currency denominated loans rather than for ruble-denominated loans. ${ }^{24}$ Also, the offsetting effect of domestic prudential policies is statistically, at the $10 \%$ level, and economically significant only for ruble-denominated loans, although the insulation is partial. ${ }^{25}$ This insulation effect is statistically

\footnotetext{
${ }^{21}$ These results are also robust to monetary-policy shocks from the U.K. and the euro area (available upon request).

${ }^{22}$ In response to an unanticipated monetary loosening in the U.S. by 0.25 p.p., the growth rate of ruble-denominated loans for a typical bank with $15 \%$ of foreign liabilities on its balance sheet will rise by 0.9 p.p. over one-year horizon. The point estimate suggests that the one-year cumulative effect of unanticipated monetary loosening in the U.S. by 0.25 p.p. on lending of a median internationally active Russian bank is 1.5 p.p.

${ }^{23}$ These results are in contrast with those including monetary-policy shocks from the United States, the United Kingdom, and the euro area where evidence in favor of an insulating effect of domestic prudential policies with regard to U.S. monetary shocks is found only in the case of foreign-currency-denominated loans but not in the case of home-currency-denominated loans. These results are available upon request.

${ }^{24}$ The point estimate suggests that the one-year cumulative effect of unanticipated monetary loosening in the U.S. by 0.25 pp on lending of a median internationally active Russian bank is $1.8 \mathrm{pp}$ for ruble-denominated loans and 3 pp for foreign-currency denominated loans.

${ }^{25}$ The point estimate suggests that under the stance of prudential policy as measured by the Cerutti et al. (2017b) overall
} 
Table 5: Chile \& Mexico. U.S. MP shocks under mortgage-related policy stance.

\begin{tabular}{|c|c|c|c|c|}
\hline \multirow[b]{2}{*}{$\begin{array}{l}\Delta M P^{U S} \\
P r u^{d} \\
\Omega\end{array}$} & \multicolumn{2}{|c|}{ Chile } & \multicolumn{2}{|c|}{ Mexico } \\
\hline & $\begin{array}{c}\text { Shock } \\
\text { LTV } \\
\text { MN/TL }\end{array}$ & $\begin{array}{c}\text { MP1 } \\
\text { LTV } \\
\text { MN/TL }\end{array}$ & $\begin{array}{l}\text { Shock } \\
\text { Prov } \\
\text { M/TL }\end{array}$ & $\begin{array}{c}\text { MP1 } \\
\text { Prov } \\
\text { M/TL }\end{array}$ \\
\hline $\begin{array}{l}\text { A. Total lending } \\
\sum_{k=0}^{K} \Omega_{b, t-K-1} \times \Delta M P_{t-k}^{U S} \\
\Omega_{b, t-K-1} \times \operatorname{Pru}_{t-K-1}^{d} \\
\sum_{k=0}^{K} \Omega_{b, t-K-1} \times \operatorname{Pru}_{t-K-1}^{d} \times \Delta M P_{t-k}^{U S} \\
\Omega_{b, t-K-1}\end{array}$ & $\begin{array}{l}0.00^{*} \\
0.06 \\
-0.00 \\
-0.03\end{array}$ & $\begin{array}{l}-0.01^{* * *} \\
0.01 \\
0.14 \\
-0.10^{* *}\end{array}$ & $\begin{array}{l}0.27 \\
0.16^{*} \\
0.10 \\
-0.17\end{array}$ & $\begin{array}{l}-0.01 \\
0.13 \\
-0.29^{* * *} \\
-0.25\end{array}$ \\
\hline $\begin{array}{l}\text { Obs. } \\
\text { No. of banks } \\
R^{2}\end{array}$ & $\begin{array}{c}807 \\
15 \\
0.53 \\
\end{array}$ & $\begin{array}{c}715 \\
15 \\
0.48\end{array}$ & $\begin{array}{c}399 \\
7 \\
0.28\end{array}$ & $\begin{array}{c}301 \\
7 \\
0.26 \\
\end{array}$ \\
\hline $\begin{array}{l}\text { B. Mortgages } \\
\sum_{k=0}^{K} \Omega_{b, t-K-1} \times \Delta M P_{t-k}^{U S} \\
\Omega_{b, t-K-1} \times \operatorname{Pru}_{t-K-1}^{d} \\
\sum_{k=0}^{K} \Omega_{b, t-K-1} \times \operatorname{Pru}_{t-K-1}^{d} \times \Delta M P_{t-k}^{U S} \\
\Omega_{b, t-K-1}\end{array}$ & $\begin{array}{l}0.00^{* *} \\
-0.10 \\
0.01^{* * *} \\
0.14^{*}\end{array}$ & $\begin{array}{l}-0.01^{* * *} \\
-0.25^{* *} \\
-0.12 \\
0.05\end{array}$ & $\begin{array}{c}1.16 \\
0.19 \\
-1.36 \\
-0.60^{* *}\end{array}$ & $\begin{array}{r}-0.01 \\
0.14 \\
-0.23 \\
-0.35\end{array}$ \\
\hline $\begin{array}{l}\text { Obs. } \\
\text { No. of banks } \\
R^{2}\end{array}$ & $\begin{array}{c}807 \\
15 \\
0.44\end{array}$ & $\begin{array}{c}715 \\
15 \\
0.38\end{array}$ & $\begin{array}{c}399 \\
7 \\
0.21\end{array}$ & $\begin{array}{c}301 \\
7 \\
0.21\end{array}$ \\
\hline
\end{tabular}

Notes: The dependent variable is log-changes in loans to the domestic non-financial private sector. The data are quarterly from 2000Q1 to 2017Q4 for a panel of all resident banks. $\Delta M P^{U S}$ refers to the SVAR identified structural U.S. monetary shocks (Shock) or the monetary surprise (MP1) defined in Subsection 2.3. For Chile, consider LTV as $\operatorname{Pru}^{d}$ with mortgage notes over total loans as $\Omega_{b, t}$, in the case of Mexico, changes in provisioning basis for Mexico with mortgage loans to total loan respectively. All specifications include the set of banks' controls $X_{b, t}$, as well as bank and time fixed effects. Standard errors are robust to cross-sectional dependence in panel estimation. ${ }^{* * *},{ }^{* *}$, and $*$ indicate significance at the $1 \%, 5 \%$, and $10 \%$ level, respectively.

insignificant for foreign-currency denominated loans, although it has the expected sign.

\subsection{The role of prudential policies targeting mortgage loans}

Table 5 presents the results of estimating equation (1) when considering the specific prudential policies targeting mortgage lending implemented in Chile and Mexico. Panel A of Table 5 reports the impact on total lending, while Panel B reports the effect on mortgage lending.

In the case of Chile, the triple interaction is not significant when considering total lending growth rates. However, we find that the LTV regulation in Chile dampers the effect of the U.S. monetary policy SVAR shock on mortgage lending (i.e a positive and statistically significant coefficient for the triple interaction).

For Mexico, Table 5 shows the case of domestic prudential policy changes that targeted mortgage provisioning, the third solid vertical line in Figure 10. For total lending, the estimated coefficient on the triple interaction between U.S. monetary policy and prudential policy, and the banks' exposure to the prudential policy is negative and statistically significant for the monetary-policy surprise measure at $1 \%$. The negative coefficient suggests that Mexico's change in mortgage provisioning stance resulted in U.S. monetary-policy tightening causing banks with relatively more exposure to mortgages, to reduce their domestic credit growth rates.

index equals 3, which roughly corresponds to the post-2010 average, the credit growth of a median bank with $15 \%$ of foreign liabilities will be by about 0.7 p.p. lower compared with a hypothetical bank with no foreign liabilities. 
Table 6: Mexico \& Russia. U.S. MP shocks under consumer-related policy stance.

\begin{tabular}{|c|c|c|c|c|}
\hline \multirow[b]{2}{*}{$\Delta M P^{U S}$} & \multicolumn{2}{|c|}{ Mexico } & \multicolumn{2}{|c|}{ Russia } \\
\hline & Shock & MP1 & Shock & MP1 \\
\hline Pru ${ }^{d}$ & $\mathrm{CCP}$ & $\mathrm{CCP}$ & Cons & Cons \\
\hline$\Omega$ & $\mathrm{CC} / \mathrm{TL}$ & $\mathrm{CC} / \mathrm{TL}$ & $\mathrm{CL} / \mathrm{TL}$ & $\mathrm{CL} / \mathrm{TL}$ \\
\hline$\overline{\sum_{k=0}^{K} \Omega_{b, t-K-1} \times \Delta M P_{t-k}^{U S}}$ & $4.01^{* *}$ & -0.09 & -0.08 & 1.51 \\
\hline$\Omega_{b, t-K-1} \times \operatorname{Pru}_{t-K-1}^{d}$ & -0.30 & 0.22 & $-0.12^{* * *}$ & $-0.15^{*}$ \\
\hline$\sum_{k=0}^{K} \Omega_{b, t-K-1} \times \operatorname{Pru}_{t-K-1}^{d} \times \Delta M P_{t-k}^{U S}$ & $-4.50^{* *}$ & 0.20 & $0.29^{* *}$ & 3.58 \\
\hline$\Omega_{b, t-K-1}$ & $-1.11^{*}$ & -1.22 & 0.03 & 0.24 \\
\hline Obs. & 399 & 301 & 744 & 711 \\
\hline No. of banks & 7 & 7 & 21 & 21 \\
\hline$R^{2}$ & 0.39 & 0.40 & 0.13 & 0.09 \\
\hline
\end{tabular}

Notes: The dependent variable is log changes in loans to the domestic non-financial private sector. The data are quarterly from $2000 \mathrm{Q} 1$ to $2017 \mathrm{Q} 4$ for a panel of all resident banks. $\Delta M P^{U S}$ refers to the SVAR identified structural U.S. monetary shocks (Shock) or the monetary surprise (MP1) defined in Subsection 2.3. All specifications include the set of controls $X_{b, t}$, as well as banks and time fixed effects. Standard errors are robust to cross-sectional dependence in panel estimation. ${ }^{* * *},{ }^{* *}$, and ${ }^{*}$ indicate significance at the $1 \%, 5 \%$, and $10 \%$ level, respectively.

\subsection{The role of prudential policies targeting consumer credit}

Finally, Table 6 reports results for changes in prudential policy targeting consumer credit, such as those implemented in Mexico and Russia during the sample period.

In the case of Mexico, the most striking results is the greater magnitude and statistical significance of the coefficient estimates using the monetary-policy shock measure. Also, the effect of U.S. monetary-policy shocks via bank exposure to the credit-card sector is positive, relatively large, and statistically significant at $5 \%$, implying a tightening shock in the United States increased credit growth for banks more exposed to the credit-card sector. ${ }^{26}$ And there is evidence that the domestic prudential policy offsets this effect, the estimated coefficient on the triple interaction between U.S. monetary policy, the bank exposure variable and the domestic prudential policy is negative and also statistically significant at $5 \% \cdot{ }^{27}$

In the case of Russia, the direct effect of U.S. monetary shocks on domestic lending is found to be statistically insignificant. In the specification with the SVAR identified U.S. monetary shock, the estimated effect of the domestic prudential policy targeting consumer credit is statistically and economically significant. ${ }^{28}$ Notice that the specifications with MP1 serving as a proxy for U.S. monetary shock did not produce statistically significant estimates, either in Mexico or in Russia. Finally, to provide further robustness to the Russian results, we estimated a set of regressions with household loans as a fraction of total assets serving as the bank exposure variable with alternative proxies for the stance of domestic prudential policy. ${ }^{29}$ This is shown in Table 9 in the Appendix. We find that the estimated effect of triple interactions involving domestic prudential policy is always positive and sometimes statistically significant. The size of the effect implies partial insulation of foreign monetary-policy spillovers in some specifications but disproportionately greater effects in others.

\footnotetext{
${ }^{26}$ As noted above, Mexico may experience "positive" inward monetary policy spillovers because of the real economy connections between the US and Mexico, both flows in labor and goods, and production value chain linkages. Thus a tightening monetary policy surprise in the US could be associated with an increase in domestic credit in Mexico.

${ }^{27}$ The communication with the banking sector regarding these regulatory changes began in late 2008 and early 2009 , with the law taking effect in 2009Q3 for credit cards. For this reason, we run the regression with various starting dates for the impact effect, ranging between the first two solid vertical lines in Figure 10. Results reported in the paper use 2009Q1 as the start date for the policy effects, but are in general consistent for different starting dates.

${ }^{28}$ The point estimate suggests that the contractionary effect of an unanticipated U.S. monetary tightening on the lending of a median Russian bank with $5 \%$ assets allocated to consumer credit under the "average" stance of prudential policy targeting consumer credit of 2 will be weaker by 2.9 p.p. compared with a hypothetical bank with no exposure to consumer credit.

${ }^{29}$ This proxy is far from perfect as, in addition to consumer credit, household loans include car loans and mortgages loans. Unlike consumer credit, which is available since 2008, this data is available for the entire sample period, 2000Q1-2017Q4.
} 


\section{Concluding remarks}

This paper investigates to what extent domestic prudential policies can insulate a small open emerging market economy from potentially unwanted spillovers of monetary policy in systemic countries that affect domestic bank lending.

We find some evidence that a tighter stance of domestic prudential policies attenuates the inward transmission of foreign monetary policy but the offsetting power of those policies differs across countries, specific channels of transmission, and specific policies.

One finding that we find remarkable is the cross-currency substitution effect in Chile: under tight reserve requirements on foreign currency deposits, banks respond to a contractionary U.S. monetary shock by cutting lending in foreign currency loans but expanding lending in local currency. No such effect, however, is documented for Russia where the transmission of the U.S. monetary shocks to the growth in local-currency loans remains unaffected.

Another interesting pattern found in the data is that the effect of prudential policies that target a specific asset type tends to be concentrated in the targeted sector, as in mortgage loans it Chile, with no influence on the total lending growth. One interpretation is that, despite the presence of frictions that limit banks' flexibility in re-balancing their loan portfolio in the short to medium term, banks nevertheless still have some room for maneuver in reallocating funds to other (non-targeted) sectors.

Finally, the Mexican results show the risks of generalizing across emerging economies. The sign of the estimated effect was not as hypothesized. The results for Mexico, suggest that when inward monetary policy spillovers from the US can be identified, they were positive, meaning a surprise tightening in the US increased credit growth in Mexico. And, when domestic prudential policy shows an interaction effect, it is offsetting, reducing the positive spillover. To the extent that the major prudential policy intervention undertaken in Mexico over the sample period, namely, the revision of loan loss provisioning rules, may be qualified as a tightening or loosening, we are focused on the estimated offsetting effect which is statistically and economically significant.

Nevertheless, one obvious challenge for our study is that we use crude measures of the prudential policy stance. Given that the set of prudential policies available to policymakers is quite heterogeneous, their quantification and aggregation is a true challenge. Development of meaningful and more flexible approaches to the measurement of prudential policy stance remains an important avenue for future research.

\section{References}

Ahumada, A. and Marshall, J. (2001). The banking industry in Chile: competition, consolidation and systemic stability. In Hawkins, J. and Mihaljek, D., editors, The banking industry in the emerging market economies: competition, consolidation and systemic stability, number 4 in BIS Papers, pages 45-53. Bank for International Settlements.

Alam, Z., Alter, A., Eiseman, J., Gelos, G., Kang, H., Narita, M., Nier, E., and Wang, N. (2019). Digging deeper-evidence on the effects of macroprudential policies from a new database. IMF Working Paper 66, International Monetary Fund, Washington, DC.

Avdjiev, S., Hardy, B., McGuire, P., and von Peter, G. (2020). Home sweet host: Prudential and monetary policy spillovers through global banks. BIS Working Paper 853, Bank for International Settlements, Basel, Switzerland.

Bank for International Settlements (2019). BIS Annual Report.

Baskaya, Y. S., Di Giovanni, J., Kalemli-Özcan, Ş., Peydró, J.-L., and Ulu, M. F. (2017). Capital flows and the international credit channel. Journal of International Economics, 108:S15-S22.

Beck, T., Demirgüç-Kunt, A., and Levine, R. (2000). A new database on financial development and structure. World Bank Economic Review, 14:597-605. 
Beck, T., Demirgüç-Kunt, A., and Levine, R. (2009). Financial institutions and markets across countries and over time: Data and analysis. World Bank Economic Policy Research Working Paper 4943, World Bank Organisation, Washington, DC.

Bräuning, F. and Ivashina, V. (forthcoming). Monetary policy and global banking. The Journal of Finance.

Buch, C. M., Bussiere, M., Goldberg, L., and Hills, R. (2019). The international transmission of monetary policy. Journal of International Money and Finance, 91:29-48.

Bussière, M., Hills, R., Lloyd, S., Meunier, B., Pedrono, J., Reinhardt, D., and Sowerbutts, R. (forthcoming). To what extent can recipient countries attenuate the impact of foreign monetary policy shocks by using domestic macroprudential policy? the perspective of the United Kingdom and France as source countries. Review of International Economics.

Cerutti, E., Claessens, S., and Laeven, L. (2017a). The use and effectiveness of macroprudential policies: New evidence. Journal of Financial Stability, 28:203-224.

Cerutti, E., Correa, R., Fiorentino, E., and Segalla, E. (2017b). Changes in prudential policy instruments: a new cross-country database. International Journal of Central Banking, 13(1):477-503.

Čihák, M., Demirgüç-Kunt, A., Feyen, E., and Levine, R. (2012). Benchmarking financial development around the world. World Bank Economic Policy Research Working Paper 6175, World Bank Organisation, Washington, DC.

Correa, R., Goldberg, L. S., and Rice, T. (2015). International Banking and Liquidity Risk Transmission: Evidence from the United States. IMF Economic Review, 63(3):626-643.

Correa, R. and Murry, C. (2010). Is there a cross-border bank lending channel? evidence from US banks' international exposure. In Research on global financial stability: the use of BIS international financial statistics, 40, pages 113-132, Basel, Switzerland. Committee on the Global Financial System, Bank for International Settlements. Proceedings of the second CGFS workshop held at the BIS in December 2008, chaired by Aviram Levy of the Bank of Italy.

Danilova, E. and Morozov, M. (2017). The macroprudential policy framework in Russia. In Macroprudential frameworks, implementation and relationship with other policies, number 94 in BIS Papers, pages 305-319. Bank for International Settlements.

Epure, M., Mihai, I., Minoiu, C., and Peydró, J.-L. (2018). Household credit, global financial cycle, and macroprudential policies: credit register evidence from an emerging country. IMF Working Paper 13, International Monetary Fund, Washington, DC.

Fernández, A., Klein, M. W., Rebucci, A., Schindler, M., and Uribe, M. (2016). Capital control measures: A new dataset. IMF Economic Review, 64(3):548-574.

Forbes, K., Fratzscher, M., and Straub, R. (2015). Capital-flow management measures: What are they good for? Journal of International Economics, 96:S76-S97.

Frost, J., Ito, H., and van Stralen, R. (2020). The effectiveness of macroprudential policies and capital controls against volatile capital inflows. Working Paper 867, Bank for International Settlements, Basel, Switzerland.

Gajewski, K., Jara, A., Kang, Y., Mok, J., Moreno, D., and Serwa, D. (2019). International spillovers of monetary policy: Lessons from Chile, Korea, and Poland. Journal of International Money and Finance, 90:175-186.

Gambacorta, L. and Murcia, A. (2017). The impact of macroprudential policies and their interaction with monetary policy: an empirical analysis using credit registry data. BIS Working Papers 636, Bank for International Settlements, Washington, DC. 
Gertler, M. and Karadi, P. (2015). Monetary policy surprises, credit costs, and economic activity. American Economic Journal: Macroeconomics, 7(1):44-76.

Gilchrist, S. and Zakrajšek, E. (2012). Credit spreads and business cycle fluctuations. American Economic Review, 102(4):1692-1720.

Giovanni, J. d., Kalemli-Özcan, S., Ulu, M. F., and Baskaya, Y. S. (2017). International spillovers and local credit cycles. NBER Working Paper 23149, National Bureau of Economic Research, Cambridge, MA.

Gürkaynak, R., Sack, B., and Swanson, E. (2005). Do actions speak louder than words? the response of asset prices to monetary policy actions and statements. International Journal of Central Banking, 1(1):55-93.

Ilzetzki, E., Reinhart, C. M., and Rogoff, K. S. (2019). Exchange arrangements entering the twenty-first century: Which anchor will hold? The Quarterly Journal of Economics, 134(2):599-646.

Jara, A. and Cabezas, L. (2017). International banking and cross-border effects of regulation: Lessons from Chile. International Journal of Central Banking, 13(2):95-127.

Jara, A. and Oda, D. (2015). Agrupación de instituciones bancarias a partir del análisis de cluster: una aplicación al caso de Chile. Documento de Trabajo 744, Banco Central de Chile, Santiago, Chile.

Jarociński, M. and Karadi, P. (2020). Deconstructing monetary policy surprises - the role of information shocks. American Economic Journal: Macroeconomics, 12(2):1-43.

Jiménez, G., Ongena, S., Peydró, J.-L., and Saurina, J. (2017). Macroprudential policy, countercyclical bank capital buffers, and credit supply: Evidence from the Spanish dynamic provisioning experiments. Journal of Political Economy, 125(6):2126-2177.

Kashyap, A. K. and Stein, J. C. (2000). What do a million observations on banks say about the transmission of monetary policy? American Economic Review, 90(3):407-428.

Korinek, A. and Sandri, D. (2016). Capital controls or macroprudential regulation? Journal of International Economics, 99:S27-S42.

Kruglova, A. and Styrin, K. (2017). Inward transmission of foreign monetary policy shocks to a small open economy in the presence of country-specific shocks: The case of russia. Bank of Russia.

Levin-Konigsberg, G., López, C., López-Gallo, F., and Martínez-Jaramillo, S. (2017). International banking and cross-border effects of regulation: Lessons from México. International Journal of Central Banking, $13(2): 249-271$.

Mertens, K. and Ravn, M. O. (2013). The dynamic effects of personal and corporate income tax changes in the united states. American Economic Review, 103(4):1212-47.

Miranda-Agrippino, S. and Ricco, G. (forthcoming). The Transmission of Monetary Policy Shocks. American Economic Journal: Macroeconomics.

Morais, B., Peydró, J., Roldán-Peña, J., and Ruiz-Ortega, C. (2019). The International Bank Lending Channel of Monetary Policy Rates and QE: Credit Supply, Reach-for-Yield, and Real Effects. Journal of Finance, 74(1):55-90.

Pasricha, G. K., Falagiarda, M., Bijsterbosch, M., and Aizenman, J. (2018). Domestic and multilateral effects of capital controls in emerging markets. Journal of International Economics, 115:48-58.

Rey, H. (2015). Dilemma not trilemma: the global financial cycle and monetary policy independence. NBER Working Paper 21162, National Bureau of Economic Research, Cambridge, MA.

Rey, H. (2016). International channels of transmission of monetary policy and the mundellian trilemma. IMF Economic Review, 64(1):6-35. 
Stock, J. H. and Watson, M. W. (2012). Disentangling the channels of the 2007-2009 recession. NBER Working Paper 18094, National Bureau of Economic Research, Washington, DC.

Takáts, E. and Temesvary, J. (2019). How does the interaction of macroprudential and monetary policies affect cross-border bank lending? BIS Working Paper 782, Bank for International Settlements, Basel, Switzerland.

\section{Appendices}

\section{A Additional figures}

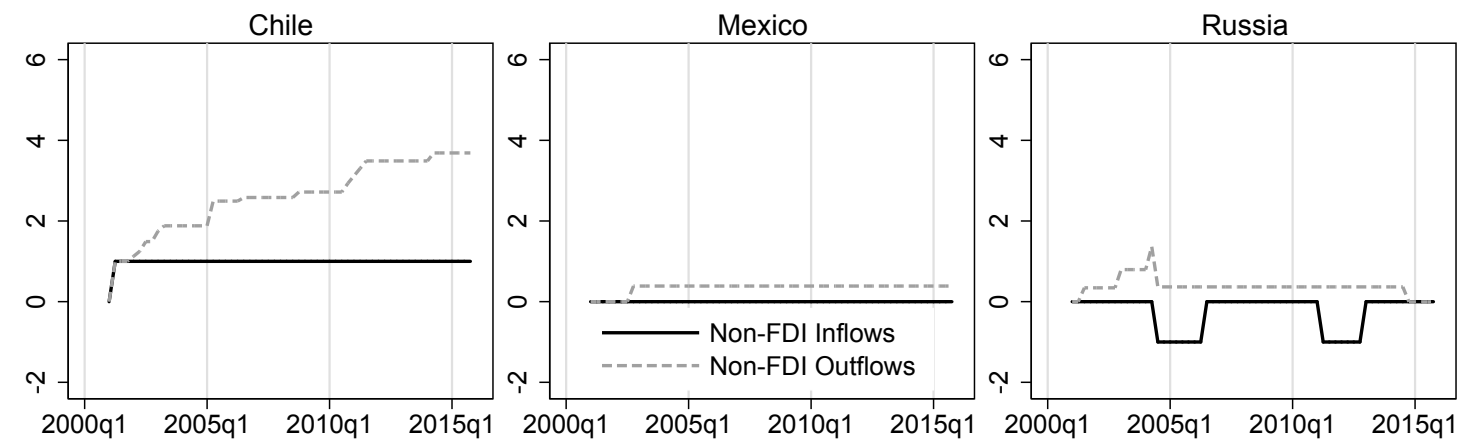

Figure 6: Capital controls on inflows and outflows. This figure shows the cumulative weighted average of net non-FDI inflows and outflows easing actions undertaken by each economy. Source: Pasricha et al. (2018).

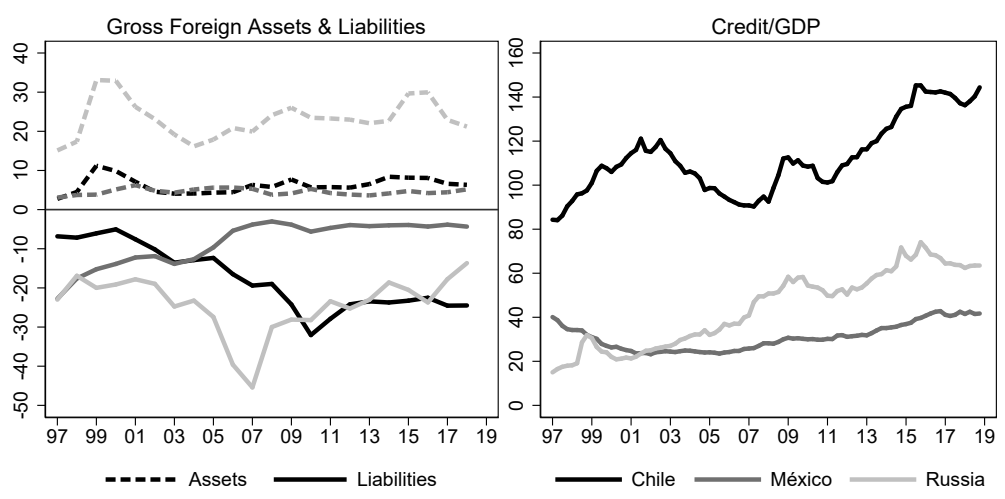

Figure 7: CMR banks' foreign positions (\% of assets) and credit to private sector (\% of GDP). The figure on the left shows gross foreign assets and liabilities of banks in CMR economies, taken from national central banks, as a percentage share of deposit institutions assets, taken from Beck et al. (2000, 2009); Čihák et al. (2012). Dashed lines show the former and solid lines, the latter. The figure on the right shows total credit to the private sector as a share of GDP, from BIS. Sources: Banco Central de Chile, Banco de México, Central Bank of the Russian Federation, International Monetary Fund, Bank for International Settlements, and the Financial Structure Database (Beck et al., 2000, 2009; Čihák et al., 2012) 


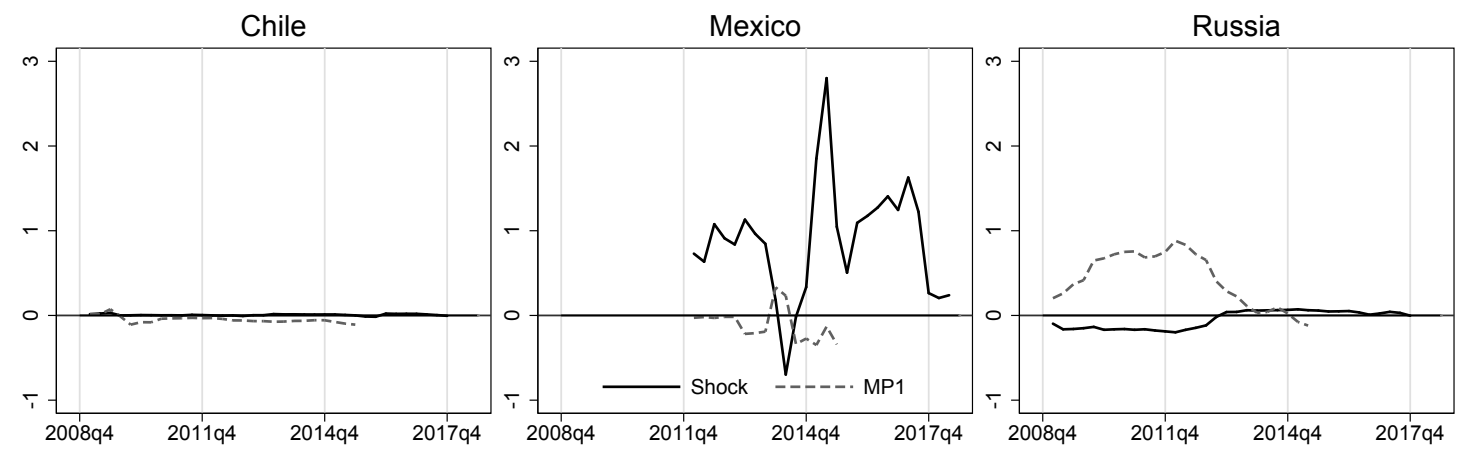

Figure 8: Rolling window estimation of the joint effect of 4-lags in the monetary policy variable on domestic lending growth rate through the exposure $\Omega_{b, t}$. In the case of Chile and Russia, it considers a moving sample of eight years, while that for Mexico is five years. The dependent variable is the log-changes of banking loans to the domestic non-financial private sector denominated in all currencies. The data are quarterly from 2000Q1 to 2017Q4 for a panel of resident banks with foreign exposures (2007q1 to 2018q2 in the case of Mexico ). $\triangle M P^{U S}$ refers to the SVAR identified structural U.S. monetary-policy shock (Shock) or the monetary-policy surprise (MP1), as defined in sub-section 2.3. The exposure measurement $\Omega_{b, t}$ corresponds to foreign-currency deposits to total liabilities in the case of Chile (FCD/TL), and non-resident liabilities to total liabilities (NRL/TL) in the cases of Mexico and Russia. All specifications include the set of control variables $X_{b, t}$, as well as time and bank fixed effects. Standard errors are robust to cross-sectional dependence in panel estimation. Source: Authors' elaboration.

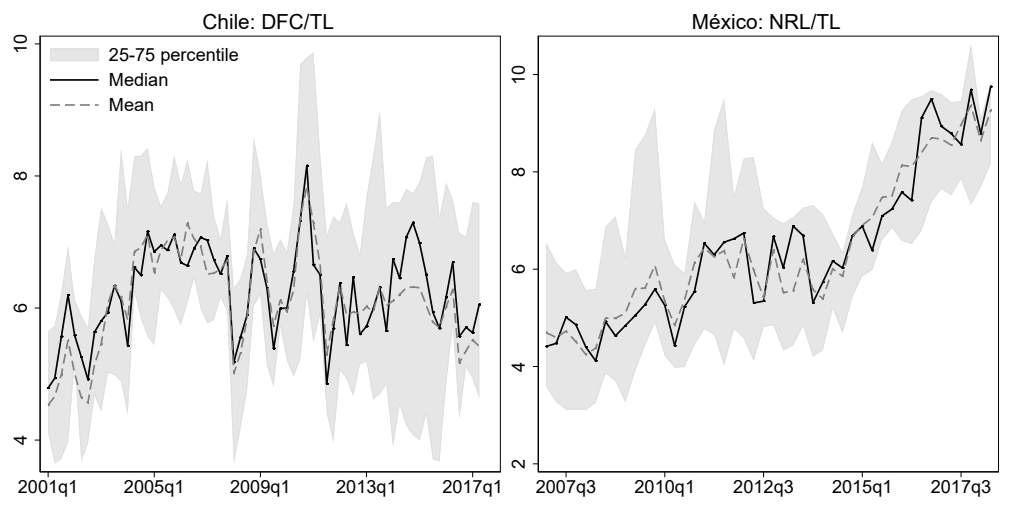

Figure 9: Chilean and Mexican banks' exposure to cumulative prudential changes. These figures show the distribution of the transmission channels for the 2-years cumulative aggregate PruP index between 2000 and 2017 for Chilean and Mexican banks. Source: Authors' elaboration. 


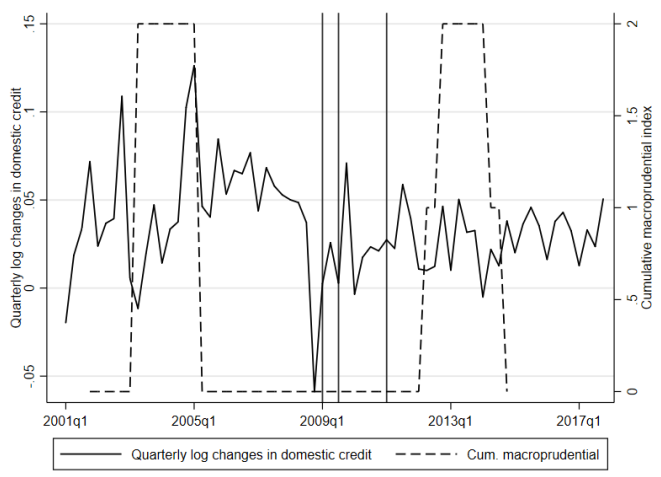

Figure 10: Mexico macro-prudential policy and domestic credit growth. This figure shows domestic credit growth and macroprudential policy measures for Mexico. The dashed line is a accumulation of changes in macroprudential policy. One time prudential changes occurred for the credit card sector in the range of the first two vertical lines, and subsequently for the mortgage sector, the third vertical line. Source: Authors' elaboration and Cerutti et al. (2017b).

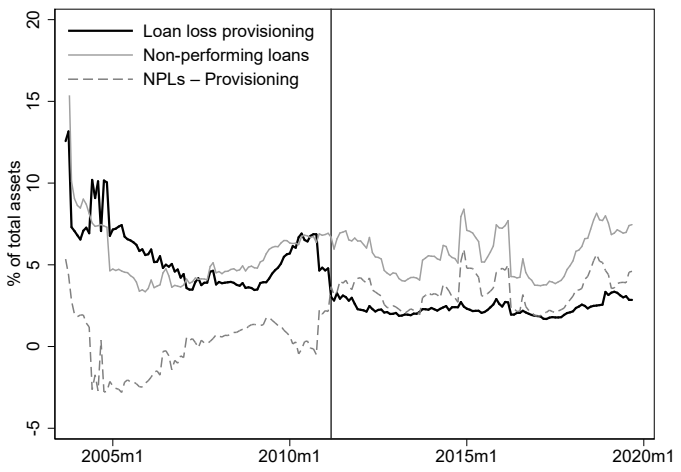

Figure 11: Mexico prudential policy: mortgages. This figure shows the evolution of delinquency and provisioning for mortgage sector loans for Mexico. A one time prudential change took effect for the mortgage sector in the first quarter of 2011, the vertical line, as part of bringing regulations into line with IFRS-9. Before the change, loan loss provisioning was based on past delinquency rates. After the rule change, banks had to use predicted default rates as the basis for provisioning. Source: CNBV, Banco de Mexico. 


\section{B Additional tables}

Table 7: Russia. Timeline of macroprudential measures since 2006

\begin{tabular}{|c|c|}
\hline \multicolumn{2}{|c|}{ Differentiated reserve requirement } \\
\hline October 2006 & $\begin{array}{l}\text { The reserve requirement on liabilities to non-resident banks in all currencies was in- } \\
\text { creased to } 3.5 \% \text { (from } 2 \% \text { ). This instrument was introduced at } 2 \% \text { in August } 2004 \text {. }\end{array}$ \\
\hline July 2007 & $\begin{array}{l}\text { The reserve requirement on liabilities to non-resident banks in all currencies was in- } \\
\text { creased to } 4.5 \% \\
\text { The reserve requirements on individual deposits in local currency and on other deposits } \\
\text { were raised to } 4 \% \text { and } 4.5 \% \text {, respectively }\end{array}$ \\
\hline October 2007 & $\begin{array}{l}\text { The reserve requirement on liabilities to non-resident banks in all currencies was re- } \\
\text { duced to } 3.5 \% \\
\text { The reserve requirements on individual deposits in local currency and on other deposits } \\
\text { were lowered to } 3 \% \text { and } 3.5 \% \text {, respectively }\end{array}$ \\
\hline January 2008 & $\begin{array}{l}\text { The reserve requirement on liabilities to non-resident banks in all currencies was in- } \\
\text { creased to } 4.5 \% \\
\text { The reserve requirements on individual deposits in local currency and on other deposits } \\
\text { were raised to } 4 \% \text { and } 4.5 \% \text {, respectively }\end{array}$ \\
\hline March 2008 & $\begin{array}{l}\text { The reserve requirement on liabilities to non-resident banks in all currencies was in- } \\
\text { creased to } 5.5 \% \\
\text { The reserve requirements on individual deposits in local currency and on other deposits } \\
\text { were raised to } 4.5 \% \text { and } 5 \% \text {, respectively }\end{array}$ \\
\hline July 2008 & $\begin{array}{l}\text { The reserve requirement on liabilities to non-resident banks in all currencies was in- } \\
\text { creased to } 7 \% \\
\text { The reserve requirements on individual deposits in local currency and on other deposits } \\
\text { were raised to } 5 \% \text { and } 5.5 \% \text {, respectively }\end{array}$ \\
\hline Sept. $2008\left(1^{\text {st }}\right)$ & $\begin{array}{l}\text { The reserve requirement on liabilities to non-resident banks in all currencies was in- } \\
\text { creased to } 8.5 \% \text {. } \\
\text { The reserve requirements on individual deposits in local currency and on other deposits } \\
\text { were raised to } 5.5 \text { and } 6 \% \text {, respectively }\end{array}$ \\
\hline Sept. $2008\left(18^{\text {th }}\right)$ & $\begin{array}{l}\text { The reserve requirement on liabilities to non-resident banks in all currencies was re- } \\
\text { duced to } 4.5 \% \text {. } \\
\text { The reserve requirements on individual deposits in local currency and on other deposits } \\
\text { were lowered to } 1.5 \% \text { and } 2 \% \text {, respectively }\end{array}$ \\
\hline October 2008 & $\begin{array}{l}\text { The reserve requirements were uniformly reduced to } 0.5 \% \text {. The reserve requirement } \\
\text { was subsequently raised to } 1 \% \text { in May } 2009 \text {, to } 1.5 \% \text { in June } 2009 \text {, to } 2 \% \text { in July } 2009 \text {, } \\
\text { and to } 2.5 \% \text { in August } 2009\end{array}$ \\
\hline February 2011 & $\begin{array}{l}\text { The reserve requirement on liabilities to non-resident legal entities in all currencies was } \\
\text { increased to } 3.5 \% \text {. } \\
\text { The reserve requirement on deposits was raised to } 3 \%\end{array}$ \\
\hline March 2011 & $\begin{array}{l}\text { The reserve requirement on liabilities to non-resident legal entities in all currencies was } \\
\text { increased to } 4.5 \% \text {. } \\
\text { The reserve requirement on deposits was raised to } 3.5 \%\end{array}$ \\
\hline April 2011 & $\begin{array}{l}\text { The reserve requirement on liabilities to non-resident legal entities in all currencies was } \\
\text { increased to } 5.5 \% \text {. } \\
\text { The reserve requirement on deposits was raised to } 4 \%\end{array}$ \\
\hline March 2013 & The reserve requirements were uniformly imposed at $4.25 \%$ \\
\hline April 2016 & $\begin{array}{l}\text { The reserve requirement on liabilities in foreign currency, except individual deposit } \\
\text { was increased to } 5.25 \% \text {. } \\
\text { The reserve requirement on other liabilities remained at } 4.25 \%\end{array}$ \\
\hline
\end{tabular}




\begin{tabular}{|c|c|}
\hline July 2016 & $\begin{array}{l}\text { The reserve requirement on liabilities in foreign currency, except individual deposits, } \\
\text { was increased to } 6.25 \% \text {. } \\
\text { The reserve requirement on individual deposits in foreign currency was increased to } \\
5.25 \% \text {. The reserve requirement on liabilities in rubles remained at } 4.25 \%\end{array}$ \\
\hline August 2016 & $\begin{array}{l}\text { The reserve requirement on liabilities in foreign currency was increased to } 6 \% \text { for indi- } \\
\text { vidual deposits and } 7 \% \text { for other liabilities. } \\
\text { The reserve requirement on liabilities in rubles was raised to } 5 \%\end{array}$ \\
\hline January 2017 & $\begin{array}{l}\text { The structure of credit institutions' reservable liabilities included in the calculation } \\
\text { of required reserves will be updated. Differentiated reserve requirements imposed on } \\
\text { long-term liabilities to non-resident legal entities and other liabilities, which had been } \\
\text { previously exempt from the rule. The reserve ratios for long-term liabilities equal the } \\
\text { previously existing reserve ratios for respective liabilities }\end{array}$ \\
\hline \multicolumn{2}{|r|}{ 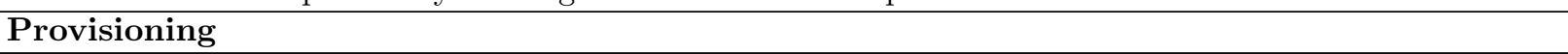 } \\
\hline June 2009 & $\begin{array}{l}\text { The loan classification and the provisioning requirement were eased (in response to a } \\
\text { banking crisis). Restructured loans were allowed to remain in the original classification }\end{array}$ \\
\hline March 2013 & $\begin{array}{l}\text { The minimum provisions for newly extended unsecured consumer loans were increased } \\
\text { to } 2 \% \text { for loans without overdue payments (from } 1 \% \text { ) and to } 6 \% \text { for loans with overdue } \\
\text { payments for no more than } 30 \text { days (from } 3 \% \text { ). The tighter provision requirements } \\
\text { were only applicable in the case that borrowers did not have deposit accounts with the } \\
\text { banks. Unsecured consumer loans with overdue payments for more than } 360 \text { days must } \\
\text { be fully provisioned (that is, } 100 \% \text { ) }\end{array}$ \\
\hline January 2014 & $\begin{array}{l}\text { The minimum provisions for newly extended unsecured consumer loans were increased } \\
\text { to } 3 \% \text { for loans without overdue payments and to } 8 \% \text { for loans with overdue payments } \\
\text { for no more than } 30 \text { days. The tighter provision requirements were only applicable in } \\
\text { the case that borrowers did not have deposit accounts with the banks }\end{array}$ \\
\hline December 2014 & $\begin{array}{l}\text { The loan classification and the provisioning requirement were eased (to increase flexi- } \\
\text { bility in the management of credit risk) }\end{array}$ \\
\hline \multicolumn{2}{|c|}{ Sectoral Capital Risk Weights } \\
\hline May 2009 & $\begin{array}{l}\text { The risk weight for relatively low-risk newly extended mortgage loans in rubles was } \\
\text { reduced to } 0.7 \text { (from 1). These mortgage loans meet the following requirements: } \\
\text { - The size of loans is less than RUB } 50 \text { million } \\
\text { - The LTV ratio is less than } 70 \% \text {; The DSTT ratio is less than } 33 \mathrm{x} / 3 \% \text { (for calculating } \\
\text { the DSTI ratio, income of spouse and children is also included) } \\
\text { - The property used as collateral must be insured for an amount of at least the size } \\
\text { of loans }\end{array}$ \\
\hline October 2011 & $\begin{array}{l}\text { The risk weight for relatively high-risk newly extended mortgage loans in rubles was } \\
\text { increased to } 1.5 \text { (from 1). These mortgage loans meet the following requirements: } \\
\text { - The size of loans is more than RUB } 50 \text { million } \\
\text { - The LTV ratio is more than } 80 \%\end{array}$ \\
\hline July 2013 & $\begin{array}{l}\text { The risk weights for newly extended unsecured consumer loans increased based on risk } \\
\text { profiles: } \\
\text { Loans in local currency } \\
\text { - Risk weight of } 1.1 \text { for loans with effective lending rates of } 25-35 \% \\
\text { - Risk weight of } 1.4 \text { for loans with effective lending rates of } 35-45 \% \\
\text { - Risk weight of } 1.7 \text { for loans with effective lending rates of } 45-60 \% \\
\text { - Risk weight of } 2 \text { for loans with effective lending rates of more than } 60 \% \\
\text { Loans in foreign currency } \\
\text { - Risk weight of } 1.7 \text { for loans with effective lending rates of } 20-25 \% \\
\text { - Risk weight of } 2 \text { for loans with effective lending rates of more than } 25 \%\end{array}$ \\
\hline January 2014 & $\begin{array}{l}\text { The risk weights for newly extended unsecured consumer loans were increased based } \\
\text { on risk profiles: } \\
\text { Loans in local currency } \\
\text { - Risk weight of } 3 \text { for loans with effective lending rates of } 45-60 \%\end{array}$ \\
\hline
\end{tabular}


- Risk weight of 6 for loans with effective lending rates of more than $60 \%$

Loans in foreign currency

- Risk weight of 3 for loans with effective lending rates of $20-25 \%$

- Risk weight of 6 for loans with effective lending rates of more than $25 \%$

May $2014 \quad$ The criteria for mortgage loans subject to the risk weight of 0.7 changed:

- The DSTI ratio is less than $50 \%$ (previously, 33\%); other criteria remain unchanged

December 2014 The risk weight for relative low-risk newly extended mortgage loans in rubles was further reduced to 0.5 . These mortgage loans meet the following requirements:

- The size of loans is less than RUB 50 million

- The LTV ratio is less than 50\%; The DSTI ratio is less than $40 \%$

- The property used as collateral must be insured for an amount of at least the size of loans

\begin{tabular}{ll}
\hline January 2015 & The risk weight for relatively high-risk newly extended mortgage loans in rubles was \\
increased to 1.5 (from 1). These mortgage loans meet the following requirements: \\
- The LTV ratio is more than $90 \%$
\end{tabular}

Source: Danilova and Morozov (2017) 
Table 8: Chile \& Russia. U.S. MP surprise under domestic 2-years cumulative prudential index.

\begin{tabular}{lccccc}
\hline & \multicolumn{2}{c}{ Chile } & & \multicolumn{2}{c}{ Russia } \\
\cline { 2 - 3 } \cline { 5 - 6 }$\Omega$ & FCD/TL & FCD/TL & & NRL/TL & NRL/TL \\
Loans & LC & FC & & LC & FC \\
\hline$\sum_{k=0}^{K} \Omega_{b, t-K-1} \times \Delta M P_{t-k}^{U S}$ & -0.00 & 0.00 & & $-0.30^{* *}$ & $-0.41^{* *}$ \\
$\Omega_{b, t-K-1} \times$ Pru $_{t-K-1}^{d}$ & 3.19 & $-3.62^{* * *}$ & & $-0.02^{* *}$ & -0.02 \\
$\sum_{k=0}^{K} \Omega_{b, t-K-1} \times P r u_{t-K-1}^{d} \times \Delta M P_{t-k}^{U S}$ & 0.20 & -0.06 & & $0.07^{*}$ & $0.08^{* *}$ \\
$\Omega_{b, t-K-1}$ & 0.04 & 0.23 & & -0.00 & -0.06 \\
\hline Obs. & 681 & 684 & & 1265 & 1265 \\
No. of banks & 13 & 13 & & 22 & 22 \\
$R^{2}$ & 0.38 & 0.48 & & 0,25 & 0,21 \\
\hline
\end{tabular}

Notes: The dependent variables are log changes in loans to the domestic non-financial private sector in local or foreign currency. The data are quarterly from 2000Q1 to 2017Q4 for a panel of all resident banks with foreign exposures. In this case, we only present the results using the surprise $(M P 1)$ as $\triangle M P$. The measure of exposure $\Omega_{b, t}$ corresponds to deposits in foreign currency as $\%$ of total liabilities in the case of Chile, and non-residents liabilities over total liabilities. All specifications include fixed effects as specified in the lower part of the table. Standard errors are robust to cross-sectional dependence in panel estimation. ${ }^{* * *},{ }^{* *}$, and ${ }^{*}$ indicate significance at the $1 \%, 5 \%$, and $10 \%$ level, respectively.

Table 9: Russia. U.S. MP shocks under alternative proxies of prudential policy stance and banks' exposures.

\begin{tabular}{lcccccc}
\hline & $(\mathbf{1})$ & $(\mathbf{2})$ & $(\mathbf{3})$ & $\mathbf{( 4 )}$ & $\mathbf{( 5 )}$ & $(\mathbf{6})$ \\
$\operatorname{Pru} u_{t}^{d}$ & Overall & Overall & Excl. RR & Excl. RR & Cons. & Cons. \\
$\Omega$ & CL/A & HL/A & CL/A & HL/A & CL/A & HL/A \\
\hline$\sum_{k=0}^{K} \Omega_{b, t-K-1} \times \Delta M P_{t-k}^{U S}$ & -0.09 & -0.16 & $-0.22^{* *}$ & $-0.17^{*}$ & -0.08 & -0.08 \\
$\Omega_{b, t-K-1} \times P r u_{t-K-1}^{d}$ & $0.01^{*}$ & 0.00 & $-0.02^{* *}$ & -0.01 & $-0.12^{* * *}$ & $-0.10^{* * *}$ \\
$\sum_{k=0}^{K} \Omega_{b, t-K-1} \times P r u_{t-K-1}^{d} \times \Delta M P_{t-k}^{U S}$ & 0.01 & 0.01 & $0.09^{* * *}$ & 0.04 & $0.29^{* *}$ & 0.16 \\
$\Omega_{b, t-K-1}$ & -0.11 & $-0.16^{*}$ & -0.00 & -0.13 & 0.03 & -0.11 \\
\hline Obs. & 744 & 1,260 & 744 & 1,260 & 744 & 1,260 \\
No. of banks & 21 & 22 & 21 & 22 & 21 & 22 \\
$R^{2}$ & 0.12 & 0.24 & 0.16 & 0.25 & 0.13 & 0.25 \\
\hline
\end{tabular}

Notes: The dependent variable is log changes in loans to the domestic non-financial private sector. The data are quarterly from 2000Q1 to 2017Q4 for a panel of all resident internationally active banks. In this case, we only present the results using he SVAR identified structural foreign monetary shocks (Shock) as $\triangle M P$. Two alternative proxies for the consumer credit channel, $\Omega_{b, t}$, are employed. These are consumer credit as a fraction of total assets ("CL/A"), and household loans as a fraction of total assets ("HL/A"). Three alternative proxies for domestic prudential policy stance are employed: 2-year cumulative overall index ("overall"), 2-year cumulative overall index without excluding reserve requirements ("excl. RR"), and 2-year cumulative consumer prudential policy sub-index ("cons."). All specifications include fixed effects as specified in the lower part of the table. Standard errors are robust to cross-sectional dependence in panel estimation. ${ }^{* * *},{ }^{* *}$, and ${ }^{*}$ indicate significance at the $1 \%, 5 \%$, and $10 \%$ level, respectively. 


\begin{tabular}{|c|c|}
\hline $\begin{array}{l}\text { Documentos de Trabajo } \\
\text { Banco Central de Chile }\end{array}$ & $\begin{array}{c}\text { Working Papers } \\
\text { Central Bank of Chile }\end{array}$ \\
\hline NÚMEROS ANTERIORES & PAST ISSUES \\
\hline $\begin{array}{l}\text { La serie de Documentos de Trabajo en versión PDF } \\
\text { puede obtenerse gratis en la dirección electrónica: }\end{array}$ & $\begin{array}{l}\text { Working Papers in PDF format can be downloaded } \\
\text { free of charge from: }\end{array}$ \\
\hline www.bcentral.cl/esp/estpub/estudios/dtbc. & www.bcentral.cl/eng/stdpub/studies/workingpaper. \\
\hline $\begin{array}{l}\text { Existe la posibilidad de solicitar una copia impresa } \\
\text { con un costo de Ch } \$ 500 \text { si es dentro de Chile y } \\
\text { US } \$ 12 \text { si es fuera de Chile. Las solicitudes se } \\
\text { pueden hacer por fax: }+56226702231 \text { o a través del } \\
\text { correo electrónico: bcch@bcentral.cl. }\end{array}$ & $\begin{array}{l}\text { Printed versions can be ordered individually for } \\
\text { US } \$ 12 \text { per copy (for order inside Chile the charge } \\
\text { is Ch } \$ 500 \text {.) Orders can be placed by fax: }+562 \\
26702231 \text { or by email: bcch@bcentral.cl. }\end{array}$ \\
\hline
\end{tabular}

DTBC -892

Labor Earnings Dispersion in Chile: Decomposition, Dynamics and the Role of Firms

Rosario Aldunate, Gabriela Contreras, Matías Tapia

DTBC -891

Determinantes del rating soberano: el caso de Chile

Natalia Gallardo, Mauricio Hitschfeld

DTBC -890

The impact of the Covid public policies on the Chilean households

Carlos Madeira

DTBC -889

Surveying the survey: What can we learn about the effects of monetary policy on inflation expectations?

Michael Pedersen

DTBC -888

Does the Exposure to the Business Cycle Improve Consumer Perceptions for

Forecasting? Microdata Evidence from Chile

Fernando Faure, Carlos A. Medel

DTBC -887

Railroads, specialization, and population growth in small open economies: Evidence from the First Globalization

Andrés Forero, Francisco A. Gallego, Felipe González, Matías Tapia 
DTBC - 886

High Dimensional Quantile Factor Analysis

Andrés Sagner

DTBC -885

Heterogeneous Paths of Industrialization

Federico Huneeus, Richard Rogerson

DTBC -884

Does the Commodity Super Cycle Matter?

Andrés Fernández, Stephanie Schmitt-Grohé, Martín Uribe

DTBC -883

Twitter-Based Economic Policy Uncertainty Index for Chile

Andrés Sagner, Juan Sebastián Becerra

DTBC -882

Corporate-Sector Functional Currency: An International Comparison

Jorge Fernández, Fernando Pino, Francisco Vásquez

DTBC -881

Back testing fan charts of activity and inflation: the Chilean case

Jorge Fornero, Andrés Gatty

DTBC -880

Financing Firms in Hibernation during the COVID-19 Pandemic

Tatiana Didier, Federico Huneeus, Mauricio Larrain, Sergio L. Schmukler

DTBC -879

Choice Aversion in Directed Networks

Jorge Lorca, Emerson Melo

DTBC -878

Big G

Lydia Cox, Gernot Muller, Ernesto Pasten, Raphael Schoenle, Michael Weber 


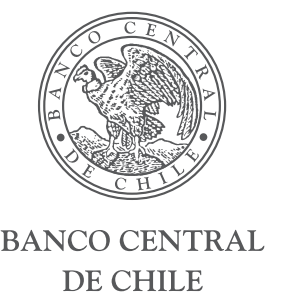

DOCUMENTOS DE TRABAJO • Diciembre 2020 